\title{
A RECRIAÇÃO DOS TERRITÓRIOS CAMPONESES POR MEIO DA PRODUÇÃO DE ALIMENTOS E ENERGIA: A EXPERIÊNCIA DO MPA EM FREDERICO WESTPHALEN-RS ${ }^{1}$
}

\author{
THE RECREATION OF PEASANT TERRITORIES THROUGH THE \\ PRODUCTION OF FOOD AND ENERGY: THE EXPERIENCE OF MPA IN \\ FREDERICO WESTPHALEN-RS
}

\section{LA RECREATION DE TERRITORIOS CAMPESINOS MEDIANTE LA PRODUCCIÓN DE ALIMENTOS Y ENERGÍA: LA EXPERIENCIA DEL MPA EN FREDERICO WESTPHALEN-RS}

\author{
Rodrigo Simão Camacho \\ rogeo@ymail.com \\ Tiago E. A. Cubas \\ tiagotec_geo05@yahoo.com.br
}

\begin{abstract}
Resumo: Consideramos a Questão Agrária brasileira como uma problemática de caráter estrutural resultante de processos enraizados na desigualdade e perversidade do modo de produção capitalista que se desdobra na disputa territorial por modelos de sociedade antagônicos, um do agronegócio e o outro do modo de vida camponês. Essa problemática envolve a Soberania Alimentar como um elemento fundamental que explicita a importância do território camponês. (Assim,) Dessa forma, a análise da Questão Agrária construída neste artigo se faz a partir da vertente campesinista do Paradigma da Questão Agrária que defende a criação e recriação dos territórios camponeses por meio de uma produção diversificada. Nessa perspectiva, temos o exemplo dos Movimentos dos Pequenos Agricultores (no Rio Grande do Sul) que atrela Soberania Alimentar e Soberania Energética como forma de resistência e recriação de seus territórios propondo uma forma de produção alternativa ao modelo do agronegócio.
\end{abstract}

Palavras-chave: Território, Camponês, Paradigmas, Soberania Alimentar e Energética.

Abstract: We consider the Agrarian Question in Brazil as a result of a structural problem of inequality and processes rooted in the perversity of the capitalist mode of production that unfolds in the territorial dispute by opposing models of society, one of agribusiness and one of the peasant way of life. This issue involves Food Sovereignty as a key element that explains the importance of territory peasant. Then, the analysis of the Agrarian Question in this article is built from the peasant slope of the Paradigm Agrarian Question advocating the creation and recreation of peasants territories through a diversified production. From this perspective, we have the example of the Movement of Small Farmers (in Rio Grande do Sul), which binds Energy Sovereignty and Food Sovereignty as a form of resistance and recreation of their territory by proposing an alternative way of producing the agribusiness model.

Key-words: Territory, Peasant, Paradigm, Food and Energy Sovereignty.

\footnotetext{
${ }^{1}$ Expansão da versão preliminar do artigo "Agrocombustíveis, soberania alimentar e políticas públicas: as disputas territoriais entre o agronegócio e o campesinato", publicado no Boletim DATALUTA em fevereiro de 2011.
} 
Resumen: Consideramos la Cuestión Agraria brasileña como una problemática de carácter estructural, como resultado de procesos que tiene sus raíces en la desigualdad y perversidad del modo capitalista de producción que se desarrolla en la disputa territorial por modelos antagónicos de sociedad, una de agribusiness y la otra del modo de vida campesino. Este problema implica la soberanía alimentaria como un elemento fundamental que explica la importancia del territorio campesino. Entonces, el análisis del Cuestión Agraria construido en este artículo es de la vertiente campesinista del Paradigma del la Cuestión Agraria que aboga por la creación y recreación de los territorios campesinos mediante la diversificación de la producción. En esta perspectiva, tenemos el ejemplo de los movimientos de los Pequeños Agricultores (en Rio Grande do Sul) que asocia Soberanía Alimentaria y la Soberanía Energética como una forma de resistencia y de la recreación de sus territorios proponiendo una forma de producción alternativa al modelo del agribusiness.

Palabras-clave: Territorio, Campesino, Paradigmas, Soberanía Alimentaria y Energética.

\section{INTRODUÇÃO}

Existe uma disputa material e imaterial em torno do debate acerca da Soberania Alimentar. A disputa materializada diz respeito às disputas territoriais entre $\mathrm{o}$ campesinato e os capitalistas do agronegócio, onde uma classe tenta desterritorializar a outra a fim de se territorializar. A territorialização do campesinato significa a produção da agricultura com diversidade e produção de alimentos. A territorialização do agronegócio significa a criação de territórios capitalistas que tem como essência a produção em grandes extensões de terra da monocultura para a exportação (commodities).

A produção de commodities coloca em risco a Soberania Alimentar, pois, significa a substituição da produção de alimentos pela produção de monocultura de soja, eucalipto, cana etc. Por outro lado, a recriação camponesa, cujo modo de vida tem como cerne principal a produção de alimentos para a sobrevivência familiar, é a solução principal para a manutenção de a Soberania Alimentar. Logo, enquanto o agronegócio coloca em risco a Soberania Alimentar, a agricultura camponesa é a protagonista deste processo.

No que se refere à disputa imaterial temos uma interpretação distinta, construída a partir de paradigmas distintos, acerca do que significa o campesinato e o agronegócio. Esses paradigmas são: o Paradigma da Questão Agrária (PQA) e o 
Paradigma do Capitalismo Agrário (PCA). Estamos utilizando para a construção deste artigo as reflexões construídas a partir do Paradigma da Questão Agrária.

Neste paradigma, estão reunidos os autores marxistas que defendem a superação do capitalismo a partir da luta classes como a única solução para a questão agrária. Dentro deste paradigma nos encontramos na tendência campesinista que defende a recriação camponesa de duas formas: por meio da contradição própria do desenvolvimento do modo de produção capitalista e por meio da luta pela/na terraterritório. Devido à contradição do capitalismo, as relações camponesas são relações não capitalistas que constroem territórios não capitalistas e/ou anticapitalistas. Estas contradições fazem com que capitalistas proprietários de terra e camponeses estejam sempre em conflito disputando territórios.

Neste processo de recriação camponesa construída pelos movimentos socioterritoriais camponeses temos a experiência do Movimento de Pequenos Produtores - MPA. Entendemos que esta experiência se enquadra na perspectiva do Paradigma da Questão Agrária, pois, estes visam construir uma produção autônoma do campesinato e romper com as relações capitalistas dominantes. A organização desse projeto se dá numa perspectiva de interação equilibrada entre a produção de alimentos e a produção de energia, projeto esse que o MPA denominou de ALIMERGIA. Busca-se com este projeto a construção da Soberania Alimentar e a Soberania Energética concomitantemente. Esta experiência pode ser visualizada em um trabalho de campo feito em Frederico Westphalen/RS em 2010.

Na perspectiva do Paradigma do Capitalismo Agrário o capital é o limite, a luta de classes se dissolve na integração entre agricultores familiares e produtores capitalistas do agronegócio. Suas propostas são sempre no sentido de estreitar as relações existentes entre os agricultores familiares e o agronegócio. Neste caso, a produção de alimentos e a produção de commodities não são conflituosas, mas apenas se complementam no cumprimento de funções distintas, o conflito e a disputa são substituídos pela integração aos mercados perfeitos. Neste paradigma, o campesinato, que significa um modo de vida e uma classe social, por ser incompatível com o capitalismo, dá lugar a uma categoria profissional moderna - agricultor familiar - em substituição as relações arcaicas antes estabelecidas pelo campesinato.

As políticas públicas para o campo são criadas sob a influência desses paradigmas. Alguns movimentos sociais e sindicais se dividem entre esses dois paradigmas, também. Assim, a questão da Soberania Alimentar é defendida pelos 
pesquisadores e pelos movimentos socioterritoriais camponeses ligados ao Paradigma da Questão Agrária, enquanto a Segurança Alimentar é defendida pelos pesquisadores e pelos movimentos socioterritoriais camponeses ligados ao Paradigma do Capitalismo Agrário. Enquanto o conceito de Soberania Alimentar está associado ao protagonismo e a autonomia dos sujeitos camponeses para produzir seus próprios alimentos, o conceito de Segurança Alimentar está associado à dependência dos sujeitos ao Estado para poder ter acesso aos alimentos.

Devido a essas disputas materiais e imateriais entre o agronegócio e o campesinato, estamos denominando os conceitos de Soberania Alimentar e de Segurança Alimentar como parte fundamental na construção e legitimação dos territórios imateriais, por isso também são territórios em disputa. Estes se materializam nos territórios camponeses a partir das políticas públicas, influenciando nas formas de interação da multidimensionalidade dos territórios camponeses e na criação de paisagens distintas.

\section{O PARAdigma da QUESTÃo AGRÁria E O PARAdigMA DO CAPITALISMO AGRÁRIO: DIFERENTES VISÕES DE MUNDO}

Para Bernardo Mançano Fernandes, podemos considerar os paradigmas como “[...] territórios teóricos e políticos que contribuem para transformar a realidade. [...]". (2004: 55). Por isso, a prevalência de um paradigma no processo de produção do conhecimento em uma determinada temática, contribui para condicionar a formação de uma determinada realidade de acordo com a visão de mundo dos teóricos que engendraram esse paradigma (FERNANDES, 2004).

A existência de diferentes paradigmas gera disputas e conflitualidades, as diferenças teóricas, políticas, ideológicas, metodológicas etc., existentes nos paradigmas levam a diferentes interpretações da realidade. Essas diferentes interpretações geram disputas que podem ser visualizadas nos debates em eventos científicos, em publicações de textos científicos, na direção das políticas públicas, nos objetivos dos movimentos sociais, na configuração de partidos políticos etc. (FERNANDES, 2008a).

Os conceitos, a teoria, o método, a perspectiva político-ideológica que rege a produção científica, principalmente, a interpretação da relação que os camponeses estabelecem com o modo de produção capitalista, são bem distintos no interior desses paradigmas. Estamos assumindo a disputa existente em torno da produção 
material/imaterial no interior de nossa sociedade desigual e estratificada em classes sociais, levando em conta que a luta de classes está em todas as esferas sociais: na universidade, nos movimentos sociais, no Estado etc.

\begin{abstract}
Desse modo, desde o momento em que foram rompidas as bases comuns de cooperação, sendo instaurados preceitos de diferenciação social, toda a produção humana, seja material ou imaterial, tem revelado ações que reforçam ou dilapidam as bases de sustentação de estruturas sociais consolidadas. Em outras palavras, advogam, a mudança ou a manutenção do status quo. Daí conclui-se que somos sujeitos políticos, pois inelutavelmente adotamos posturas que, dentro de uma sociedade desigual, manifestam posicionamentos favoráveis ou contrario à ordem vigente. (ALMEIDA; PAULINO, 2000: 113, grifo nosso).
\end{abstract}

Entendemos, portanto, que as correntes, tendências, posturas ou abordagens se organizam de forma encadeada dentro de um paradigma, conduzindo e direcionando as pesquisas. Nesse sentido, cada corrente apresenta sua perspectiva de estudo que incluem: seus conceitos, suas concepções filosóficas, suas orientações epistemológicas, suas terminologias, seu método, seus posicionamentos político-ideológicos etc., construindo um pensamento com características que se diferenciam em relação aos demais paradigmas (FELÍCIO, 2010).

Cada paradigma tende a disputar adeptos, conformar grupos de pesquisa, consolidar linhas de pesquisa, criar escolas de pensamento, transformar políticas públicas, mudar legislações, de modo a legitimar seus territórios. Todavia, essa multiplicidade de interpretações da realidade também revela, dialeticamente, a unidade, ou seja, os paradigmas são construídos para a interpretação de uma determinada realidade em comum. Juntos, unidade e diversidade referendam a diferencialidade paradigmática (CAMPOS; FERNANDES, 2011).

No caso específico da questão agrária, temos diferentes leituras constituídas a partir de diferentes paradigmas que incluem distinções de teoria, metodologia, método, perspectiva política, ideológica etc., dos autores que discutem essa problemática. Essas concepções levam a construção de diferentes paradigmas que se contrapõem ou dialogam dialeticamente na produção do conhecimento científico acerca da questão agrária. Em todo o Brasil a questão agrária pode ser encontrada em diversos territórios materiais e imateriais, como nos territórios dos assentamentos, acampamentos, propriedades camponesas, latifúndios improdutivos, grandes propriedades do agronegócio com suas monoculturas de cana, soja e laranja. 
Os territórios imateriais se fazem evidentes na disputa pelas ideias e pela propagação das mesmas, como vemos nas manifestações dos movimentos socioterritoriais camponeses nas estradas, cidades, rodovias, prédios públicos, e também nas manifestações dos ruralistas nos conhecidos agrishows, rodeios ou feiras agropecuárias. Os territórios imateriais das políticas públicas se materializam então nas metas econômicas do governo, nos objetivos dos partidos políticos, nas pautas dos movimentos socioterritoriais, nas escolas do campo e da cidade. E na universidade por meio dos artigos, dissertações, teses, livros e ações políticas do cotidiano acadêmico. E todas essas ações se desdobram na representação desses territórios no território dos veículos de comunicação de massa, televisão, jornais, revistas etc.

\begin{abstract}
A questão agrária está presente no nosso cotidiano há séculos. Pode-se querer não vê-la, encobrindo deliberadamente parte da realidade, mas ela se descortina dia-a-dia. Pode-se afirmar que é uma coisa do passado, mas é do presente, está ali, aqui e naquilo, em todo o lugar, ação e objeto. Em cada estado brasileiro a questão agrária se manifesta, principalmente, nas ocupações e nos acampamentos, nas estradas e nas praças. Igualmente está presente nos latifúndios, no agronegócio e nas "commodities"; nas teses, livros e relatórios. No dia-a-dia é exposta nas manchetes dos jornais e de todas as mídias que explicitam a sua conflitualidade. [...]. (FERNANDES, 2008a: 177, grifo do autor).
\end{abstract}

Nesse contexto, dentre as disputas paradigmáticas existentes na produção do conhecimento científico vamos tratar especificamente daquelas que dizem respeito às explicações acerca da questão agrária. Partimos das transformações que ocorreram/ocorrem no campo devido ao movimento de desenvolvimento do capitalismo, que nos trazem desafios para o entendimento do elemento principal de nossa preocupação, qual seja o campesinato. A análise desses sujeitos vai perpassar toda a nossa reflexão em torno dos dois paradigmas estudados: Paradigma da Questão Agrária e Paradigma do Capitalismo Agrário.

Esses dois paradigmas possuem métodos distintos, isto quer dizer que eles projetam visões de mundo distintas (FERNANDES, 2008a). A escolha de um paradigma requer que elegemos autores, conceitos e teorias, essa é uma forma de se fazer uma classificação, e isto requer que façamos uma opção de termos e conceitos. Cada uma dessas terminologias empregadas está impregnada de valores, intencionalidades e ideologias. Por isso, o cerne da questão da classificação seria, então, a opção político- 
ideológica que fazemos, pois, é esta opção que engendra os conceitos e a teoria (SANTOS apud PAULINO, 2006).

Este debate científico entre os dois paradigmas envolve reflexões antigas como o fim do campesinato (Paradigma da Questão Agrária) discutido desde as obras seminais que tratam sobre a questão agrária, até as discussões mais atuais relacionadas à metamorfose do campesinato (Paradigma do Capitalismo Agrário), ou seu oposto, sua criação e recriação na contradição, na resistência e na luta (Paradigma da Questão Agrária).

Assim, Munir Jorge Felício (2010) afirma que neste confronto dos Paradigmas, as antigas afirmações sobre o fim do campesinato vêm sendo substituídas pelas leituras da metamorfose do camponês em agricultor familiar de um lado e a recriação/recampesinização de outro. Dessa forma, teríamos três bases principais nas quais se estruturam nossa discussão: o fim do campesinato; a recriação/recampesinização e a metamorfose do campesinato em agricultor familiar.

Partimos da perspectiva de que o Paradigma da Questão Agrária é formado por autores que defendem que a Questão Agrária é um problema estrutural, logo, somente poderá ser resolvido com a luta contra o capitalismo.

Neste paradigma, o fim do campesinato é uma concepção presente desde a primeira obra que originou o Paradigma da Questão Agrária: “A Questão Agrária” de K. Kautsky. Essa obra consiste na afirmação de que o desenvolvimento do capitalismo no campo tende a, necessariamente, expropriar o campesinato e proletarizá-lo, ou seja, ocorrerá uma inevitável destruição do campesinato (OLIVEIRA, 1999; 2004; FERNANDES, 2009).

Todavia, é necessário esclarecermos que participamos de um grupo de pesquisadores que defendem a existência da recriação camponesa. Fazemos a análise das problemáticas do espaço rural a partir do Paradigma da Questão Agrária no interior da vertente que entende que o desenvolvimento do capitalismo no campo se faz a partir de um movimento desigual e contraditório (OLIVEIRA, 1999; 2004, FERNANDES, 2001).

Isso significa que existe um processo de produção de capital por meio de relações não-capitalistas (MARTINS, 1981; OLIVEIRA, 1986). Por isso, o campesinato é uma classe social e um modo de vida heterogêneo e complexo inerente à contradição do modo de produção capitalista e não um resíduo social em vias de extinção (SHANIN, 1983). Ele se recria, assim, na contradição estrutural e por meio da 
compra e da luta pela terra na sua resistência ao capital (OLIVEIRA, 1997; 1999; 2004; FERNANDES, 2001; 2008a; ALMEIDA, 2003; 2006).

$\mathrm{O}$ terceiro debate, o da metamorfose do campesinato em agricultor familiar, pertence ao Paradigma do Capitalismo Agrário, tem como principal representante Ricardo Abramovay e sua tese de doutorado publicada em 1992 com o título Paradigmas do Capitalismo Agrário em Questão. Nessa tese, ao romper com o Paradigma da Questão Agrária, ou com o debate marxista da questão agrária, o autor defende que os camponeses nem vão se proletarizar e nem se transformarão em capitalistas, como diziam os clássicos marxistas. Mas, também, não vão continuar existindo como camponeses, pois, as relações camponesas são incompatíveis com as relações de mercado capitalista.

O que o autor defende é que esses sujeitos sofreram uma metamorfose a partir da sua integração plena ao capital, auxiliados pelas políticas públicas, e se tornaram os agricultores mais eficientes de nossa época. Neste caso, esses sujeitos, ex-camponeses, passaram a serem denominados de agricultores familiares, profissionais, modernos, integrados etc. Criando, assim, uma dicotomia onde o arcaico, ineficiente, miserável e condenado a desaparecer é o camponês e, por outro lado, o moderno, eficiente, próspero e compatível com o mercado é o agricultor moderno/profissional.

De maneira geral, o Paradigma do Capitalismo Agrário trabalha na perspectiva de integração do agricultor ao capital. Assim, a subalternidade e a expropriação são vistos como sendo resultado de uma suposta ineficácia do campesinato (FERNANDES, 2008a). Entretanto, no Paradigma da Questão Agrária, essa integração é sinônimo de subordinação da renda do campesinato ao capital e, consequentemente, de produção de capital por meio de relações sociais não capitalistas (MARTINS, 1981; OLIVEIRA, 1997; 1999; 2004).

Nesses processos, o camponês não é expropriado, mas sua renda fica subordinada ao capital, e uma dessas formas, o obriga a repassar o produto do seu trabalho para o capitalista (OLIVEIRA, 2004). Essa parte da renda camponesa, que é apropriada pelo capitalista, é utilizada por este para reprodução/acumulação de capital (MARTINS, 1981). Apesar de permitir que o campesinato continue se reproduzindo, essa condição faz com que o camponês se reproduza numa situação precária, daí a necessidade de uma ruptura com o capital (ALMEIDA, 2006). Essa interpretação do Paradigma da Questão Agrária está relacionada ao fato de que para os pesquisadores 
deste paradigma o problema do campesinato é estrutural (FERNANDES, 2008a), por isso, ele só pode ser resolvido com a ruptura das estruturas socioeconômicas vigentes.

No entanto, na perspectiva do Paradigma do Capitalismo Agrário o problema é conjuntural e, portanto, não é uma questão de ruptura, mas de adaptação do campesinato ao modelo socioeconômico vigente. Logo, o problema passa a estar centrado individualmente nos sujeitos, os camponeses. Nesse contexto, podemos sintetizar as diferenças entre estes paradigmas da seguinte maneira: "[...] Para o paradigma da questão agrária o problema está na estrutura e para o paradigma do capitalismo agrário, o problema está no camponês". (FERNANDES; WELCH; GONÇALVES, 2010: 3).

A resistência também é um conceito presente no Paradigma da Questão Agrária, na perspectiva do debate da permanência camponesa pela luta na/pela terraterritório. Esses processos estão, assim, diretamente vinculados às abordagens de destruição e recriação do campesinato e seus territórios. Sendo assim, segundo Munir Jorge Felício (2010), a resistência diz respeito a todo embate do campesinato frente às condições impostas pelo capital, quer seja desterritorializando/proletarizando ou monopolizando o território camponês.

No Paradigma do Capitalismo Agrário não existe essa abordagem, pois, neste paradigma não existe o conflito de classes e as disputas territoriais que compõem a base fundamental de reflexão da geografia agrária no Paradigma da Questão Agrária. A classe camponesa é trocada pela profissão de agricultor, as disputas territoriais são trocadas pela relação de complementaridade entre o grande produtor capitalista (agronegócio) e o pequeno produtor (agricultor familiar), ou seja, agronegócio e agricultura familiar se complementam cada um cumprindo sua função social: de um lado a produção de commodities e do outro lado a produção de alimentos. Esse processo não tem, necessariamente, conflitos ou antagonismos desde que o Estado o conduza.

A resistência e a ruptura são trocadas pela integração/adaptação ao mercado capitalista. Essa integração ao mercado capitalista pode ser adquirida por meio de políticas públicas de cunho neoliberal como o Pronaf (Programa Nacional de Fortalecimento da Agricultura Familiar), o PNPB (Programa Nacional de Produção e Uso de Biocombustíveis) etc. Nessa perspectiva, os agricultores precisam pensar sua propriedade como uma pequena empresa familiar, ao invés de um território de uma classe e um modo de vida que disputa/resiste ao capital territorializado no campo. 
Por isso, a característica marcante que delimita o antagonismo dialético entre esses dois paradigmas é a afirmação da luta de classes e o campesinato como parte inerente da luta de classes, por parte do Paradigma da Questão Agrária, e a negação das classes sociais e a substituição do conceito de campesinato pela sua metamorfose em agricultor familiar, por parte do Paradigma do Capitalismo Agrário. Na metamorfose do camponês em agricultor familiar ocorre a conversão daquilo que era um modo de vida numa profissão (ABRAMOVAY, 1992).

Nesse sentido, temos de um lado, no Paradigma da Questão Agrária, a crítica ao modelo vigente, principalmente, aos impactos socioterritoriais causados pela expansão do agronegócio, e a perspectiva de superação desse modelo apontando para a possibilidade e a necessidade de construção de um outro modelo, por meio da luta/disputa/conflitos territoriais entre classes e grupos sociais.

Do outro lado, no Paradigma do Capitalismo Agrário, temos a defesa à adaptação/integração que auxilie no processo de produção/reprodução/acumulação de capital, numa perspectiva de estilos diferentes de produção e de complementaridade entre o grande produtor rural e o agricultor familiar.

[...] a) as críticas do paradigma da questão agrária aos impactos socioterritoriais, por exemplo: desmatamento, intensificação da exploração do trabalho, casos com uso de trabalho escravo, subordinação e expropriação de camponeses [...] b) as ênfases do paradigma do capitalismo agrário aos processos de "integração" aos mercados capitalistas, analisando tendências, logísticas, redes, preços etc. Não há, nesses paradigmas, estudos sobre as conflitualidades presentes nos mercados e as perspectivas de superação. (FERNANDES; WELCH; GONÇALVES, 2010: 4, grifo nosso).

Nessa disputa de territórios imateriais, podemos explicitar os antagonismos dos princípios dos dois paradigmas, a partir dos conceitos fundamentais presentes em cada um destes paradigmas. No Paradigma do Capitalismo Agrário: Problema Conjuntural, Biocombustíveis, Integração, Agricultura Familiar, Segurança Alimentar etc. Em oposição, respectivamente, aos conceitos presentes no Paradigma da Questão Agrária: Questão Estrutural, Agrocombustíveis, Subordinação, Agricultura Camponesa, Soberania Alimentar etc.

Esses conceitos são opções teóricas, políticas e ideológicas que estão presentes nas disputas em torno dos paradigmas acadêmicos, das políticas públicas e das disputas territoriais entre o agronegócio e o campesinato, envolvendo nesse processo: a academia, o Estado e os movimentos sociais. Esses conflitos fazem parte de um mesmo 
conjunto estrutural de processos dinâmicos que envolvem a insuperável questão agrária no interior do modo de produção capitalista.

\section{AS DISPUTAS TERRITORIAIS E PARADIGMÁTICAS: OS TERRITÓRIOS ANTICAPITALISTAS DO CAMPESINATO}

A importância do território para apreendermos a realidade se traduz em capturar as contradições existentes no presente, tendo em vista que as políticas públicas se desenham no território através de propostas antagônicas de projetos políticos que são projetadas (dependendo o paradigma) na perspectiva do crescimento econômico ou do desenvolvimento socioterritorial. A análise do território é estratégica, pois, é onde as relações sociais mediadas nas relações de poder realizam as vontades e interesses de classe. Esse é o espaço onde as classes sociais se realizam e, entendê-lo enquanto essência material e imaterial proporciona o olhar geográfico-histórico sobre como as ações políticas (oficiais ou extraoficiais) se situam, transformam ou não as relações sociais (sociológicas).

Os modelos antagônicos de desenvolvimento agrário influenciam nas relações sociais, configurando o território. Esses modelos de desenvolvimento são visões de mundo espacializadas nas ações humanas pelas relações de poder que, por sua vez, desembocam nas políticas públicas. As políticas públicas estão intimamente relacionadas às relações de poder que se dão no espaço formando os territórios, e assim, influem diretamente no que é visível e invisível da realidade. Apesar de sabermos que as políticas públicas não representam a totalidade da configuração territorial, mas assim como as ações humanas de resistência e (re)criação do campesinato que formam o território, elas auxiliam direta e indiretamente na territorialização de um ou outro ator social.

Os discursos dos paradigmas incorporam ideologias que buscam legitimar ou desconstruir as políticas sociais. Dependendo o paradigma, essa legitimação ou destruição se dá para o crescimento econômico ou para o desenvolvimento socioterritorial. Assim, vemos a necessidade de entendermos o território como possibilidade da construção do espaço camponês, entendendo estes como espaços 
formados por relações sociais anticapitalistas, que revelam o paradigma do desenvolvimento socioterritorial ${ }^{2}$ nos projetos políticos e nas políticas públicas.

Todavia, também podemos visualizar a territorialização das relações sociais capitalistas e junto com as mesmas a expansão das suas ideias nos territórios (de maneira agressiva), o que pretende manter as hegemonias. É contra isso que os movimentos socioterritoriais ${ }^{3}$ vêm lutando. Os desafios instalados para os movimentos socioterritoriais e os efeitos sobre os trabalhadores tem sido grandes (as sequelas para os trabalhadores: lançados ao desemprego, precarização do trabalho e flexibilização das condições de emprego). O desmantelamento da produção industrial gerou uma crise que vai desde a fragmentação dos trabalhadores (em suas agremiações) até a perda da sua identidade de classe.

Contudo, autores como Stedile (1997), Quijano (2004) e Fernandes (2008a) veem um período da constituição de novos sujeitos sociais (mecanismos de reivindicação, discurso e formas de organização voltadas para luta pelo território e pela expansão do mesmo, do território para além da terra). $\mathrm{O}$ caso brasileiro remete ao aumento das disputas territoriais, da violência dos ruralistas contra os camponeses (exemplo do papel do MST e da luta pela reforma agrária). A identidade de luta não é contra um novo inimigo, é na verdade as metamorfoses dos territórios capitalistas que se expandem com o discurso ideológico do moderno agronegócio.

Em toda a América Latina observamos os movimentos socioterritoriais levantando suas bandeiras. Nessa perspectiva, como estratégia contra-hegemônica os seus territórios adquirem outras funcionalidades. A questão não é dizer que existem territórios desvinculados do modo de produção capitalista, pois, o capital busca subordinar todas as relações sociais mesmo sem transformá-las em relações capitalistas. Mas, temos a partir dos movimentos socioterritoriais camponeses, com a conquista do território camponês, a possibilidade da construção das relações sociais não impregnadas pelo capital.

Vemos na organicidade dos movimentos socioterritoriais (como MST e MPA) seis setores principais: Educação (Educação do Campo), Político e Ideológico (formação de líderes), Comunicação (a difusão da interpretação camponesa da

\footnotetext{
${ }^{2}$ Forma de desenvolvimento não capitalista que busca atingir a multidimensionalidade do território: o social, o político, o cultural e o econômico.

${ }_{3}$ Movimentos que tem como objetivo principal a disputa e a conquista de territórios. Exemplo: o Movimento dos Trabalhadores Rurais Sem Terra que disputam territórios com o agronegócio.
} 
realidade), Produção (cooperativismo e associativismo), Cultura (que permite a (re)produção da cultura camponesa) e Frente de Massas (Organização de mobilizações).

É necessário entendermos que esses movimentos possuem novas maneiras de se movimentar e lutar pelo território. A expansão das relações sociais não capitalistas e as dinâmicas consequentes delas em contraste com a força do capital nos mostram que a América Latina está em disputa pela terra e pelas ideias.

E a partir disso, quando pensamos no conceito de território temos que imediatamente olhar para a realidade e ver as suas possibilidades. Um dos fatores fundamentais para a expansão da utilização desse conceito foi o fomento ao debate da Geografia Crítica em consonância com a potencialidade teórico-prática do mesmo em servir para entendermos a realidade através da dialética das suas transformações histórico-geográficas. Por isso separamos em três elementos destacados para alicerçar a contribuição do território para ler a realidade, e como podemos instrumentalizar cada um deles no cotidiano das relações sociais e de poder recorrentes no mundo.

\section{Elemento 1:}

O pressuposto inicial para analisarmos a realidade olhando para o território é tratar de modo indissociável a correlação entre tempo e espaço, sabendo que os dois pré-existem a formação do território. “O espaço é a 'prisão original' e o território é a prisão que os homens constroem para si” (RAFFESTIN, 1993: 144). O território é coexistente a ação humana no espaço e no tempo, que prevê conflitos de interesses que formam as relações sociais e de poder. É necessário entender o conceito de território como relações sociais, de diálogo e de disputa, mediadas pelas relações de poder e que também são determinadas por esse movimento indissociável, dialeticamente, nesse processo histórico-geográfico. As relações sociais humanas se realizam por homemhomem e homem-natureza-homem, todo processo relacional se volta para a territorialização das ações humanas desenhando no espaço diferentes territórios.

\section{Elemento 2:}

Assim, o território se origina a partir da ação das relações humanas, das relações de disputa pelo espaço e de como moldá-lo. Por isso esse conceito, com base em Fernandes (2009), para nós se torna uma ferramenta imprescindível para entendermos a partir da governabilidade, da propriedade e das relações sociais o que se passa no cenário agrário na América Latina, sendo que este é fruto da expansão 
territorial que ocorre em outros lugares no mundo. Disso decorre, a nosso ver, o segundo elemento que vai ao encontro de instrumentalizar o território, sendo esse transversal, pois, por meio dele observamos a sobreposição de ideologias, paradigmas e de intencionalidades, no qual vemos a multiterritorialidade. A multiterritorialidade nos fornece subsídios essenciais para entendermos também a multiescalaridade e a multidimensionalidade das relações que vão de escalas micro locais ao global em suas distintas dimensões de atuação (política, econômica, ambiental, cultural, social e natural).

\section{Elemento 3:}

O território não é terra, não é ideia, não é ideologia, não é cultura, não é política, não é economia, mas ele é a soma de todos esses fatores nas ações humanas que transformam o espaço (a partir da transversalidade de todos esses elementos). $\mathrm{O}$ território é caracterizado como trunfo nas ações humanas e fundamenta a interpretação geográfica dos movimentos socioterritoriais, como aqueles que vislumbram terra como parte importante de um território (FERNANDES, 2005). O território em suas vertentes material e imaterial inaugura a possibilidade de entender que todo movimento socioterritorial luta por seu território. Pensando as conexões existentes em: território/terra, território/ideologia, território/relações de produção e território/relações de vida etc. o território também é imaterial, pois, ele representa visões de mundo que se territorializam todos os dias em nossas ações. Até mesmo o fato de interrompermos por vontade própria, ou reprimirmos, uma ação, revela uma materialidade humana territorializada na não realização da mesma, ou seja, de um modo ou de outro tudo se materializa (negligenciar também é materializar-se). O território imaterial é resultado de toda materialidade e imaterialidade, tudo que se forma a partir do território material. A ideia, a ideologia e o paradigma se desdobram no território e também de modo recíproco são formados.

De forma a sintetizar, e não dicotomizar, mas pensar a mesma realidade vista de territórios antagônicos temos o Quadro 1. 
Quadro 1 - Um olhar para entender os territórios: os territórios do capital e do anticapital, suas significações, elementos e visões de mundo ${ }^{4}$

\begin{tabular}{|c|c|c|}
\hline & \multicolumn{2}{|c|}{ Territórios e as suas significações } \\
\hline Forma político- & Território capitalista & Território anti-capitalista \\
\hline $\begin{array}{l}\text { Sustentação } \\
\text { metodológica }\end{array}$ & $\begin{array}{l}\text { Na dicotomização (retórico e } \\
\text { coeso); } \\
\text { - Adaptação ou Destruição; } \\
\text { - A partir das suas lacunas que } \\
\text { ele torna forte e poderoso, porque } \\
\text { essas lacunas não são explicadas; } \\
\text { - discurso único (historiografia de } \\
\text { disputas territoriais conjunturais). }\end{array}$ & $\begin{array}{l}\mathrm{Na} \text { dialética (tese, síntese } \\
\text { antítese); } \\
\text { - Desconstrução e Emancipação } \\
\text { - Parte das lacunas do capital, das } \\
\text { suas fissuras que deixam espaço } \\
\text { para criatividade do território anti- } \\
\text { capitalista de se reproduzir; } \\
\text { - contra-discurso (historiografia de } \\
\text { disputas territoriais estruturais que } \\
\text { se dão no entre classes). }\end{array}$ \\
\hline Relações estabelecidas & $\begin{array}{l}\text { Capitalistas (exploração, mais- } \\
\text { valia e lucro). }\end{array}$ & $\begin{array}{l}\text { Não-capitalistas (auto-exploração e } \\
\text { auto-consumo). }\end{array}$ \\
\hline Enfoque territorial & $\begin{array}{l}\text { Aparência (sobreposição dos } \\
\text { valores economicistas } \\
\text { políticos); } \\
\text { - O território do capital se situa } \\
\text { em aparentar a realidade como } \\
\text { discurso único, e essa é a sua } \\
\text { essência, a razão de não se } \\
\text { explicar por completo, e assim } \\
\text { ele se torna forte. Esse território é } \\
\text { legitimado então quando o que } \\
\text { está posto é a resolução para } \\
\text { todas as coisas. }\end{array}$ & $\begin{array}{l}\text { Essência (sobreposição dos valores } \\
\text { culturais, ambientais e sociais); } \\
\text { - A imagem territorial (aparência) } \\
\text { não pode ser atribuída a totalidade, } \\
\text { ela apenas faz parte de uma } \\
\text { realidade muito mais complexa do } \\
\text { que vemos, o invisível (ou aquilo } \\
\text { que ainda não foi escancarado) é o } \\
\text { desafio do território imaterial do } \\
\text { anti-capital. }\end{array}$ \\
\hline Visão estrutural & $\begin{array}{l}\text { Integração ("entregação"); } \\
\text { - Individualismo (o singular } \\
\text { como universal). }\end{array}$ & $\begin{array}{l}\text { Desconcentração (emancipação); } \\
\text { - Individualidade (diversidade) e } \\
\text { coletividade. }\end{array}$ \\
\hline Visão conjuntural & $\begin{array}{l}\text { Expansão (subordinação); } \\
\text { - novas formas de eliminação dos } \\
\text { intermediários, otimização da } \\
\text { mais-valia e lucro; } \\
\text { - embate capitalista na sanha de } \\
\text { apropriação do trabalho e do } \\
\text { trabalhador. }\end{array}$ & $\begin{array}{l}\text { Soberania territorial (resistência, } \\
\text { transformação e superação); } \\
\text { - novas formas de resistência, } \\
\text { criação e recriação; } \\
\text { - embate anti-capitalista que não } \\
\text { somente nega mas também é } \\
\text { propositiva. }\end{array}$ \\
\hline & \multicolumn{2}{|c|}{ Territórios e a Questão Agrária } \\
\hline $\begin{array}{l}\text { Modelo de reprodução } \\
\text { socioeconômica }\end{array}$ & $\begin{array}{l}\text { Agronegócio e (agro)empresa } \\
\text { familiar (negócio e profissão) }\end{array}$ & $\begin{array}{l}\text { Agricultura familiar camponesa } \\
\text { (modo de vida e classe social) }\end{array}$ \\
\hline $\begin{array}{l}\text { Natureza da produção } \\
\text { agrícola }\end{array}$ & $\begin{array}{l}\text { Monocultura (para } \\
\text { agroexportação - comoditties). }\end{array}$ & $\begin{array}{l}\text { Produção diversificada (para } \\
\text { Soberania Alimentar). }\end{array}$ \\
\hline Tecnologia & $\begin{array}{l}\text { Alta mecanização (otimização da } \\
\text { produtividade para a viabilidade } \\
\text { da dimensão econômica em } \\
\text { detrimento do social, cultural e } \\
\text { ambiental). }\end{array}$ & $\begin{array}{l}\text { Mecanização como ferramenta } \\
\text { (busca do domínio do sistema } \\
\text { produtivo para a viabilidade da } \\
\text { reprodução familiar com ênfase no } \\
\text { social, cultural e ambiental). }\end{array}$ \\
\hline Elemento fundante & $\begin{array}{l}\text { Economia capitalista de produção } \\
\text { (acúmulo de capital, excedente } \\
\text { para lucro, apropriação da mais- } \\
\text { valia); } \\
\text { - mercado de uma economia }\end{array}$ & $\begin{array}{l}\text { Economia familiar de produção } \\
\text { (modelo de produção simples de } \\
\text { mercadoria, transformação de } \\
\text { mercadoria em dinheiro para } \\
\text { reprodução familiar); }\end{array}$ \\
\hline
\end{tabular}

\footnotetext{
${ }^{4}$ Esse quadro é baseado na leitura dos trabalhos de: Chayanov (1974), Shanin (1983), Mészáros (2005 e 2007), Oliveira (1997), Fernandes (2008a, 2008b e 2008c) e Thomaz Jr. (2007), Raffestin (1993), Haesbaert (2006), Saquet; Sposito (2009).
} 


\begin{tabular}{|c|c|c|}
\hline & $\begin{array}{l}\text { capitalista } \\
\text { perversamente. }\end{array}$ & $\begin{array}{l}\text { - mercados alternativos de uma } \\
\text { economia solidária e equitativa. }\end{array}$ \\
\hline Mão-de-obra empregada & $\begin{array}{l}\text { Pouca uso de mão-de-obra } \\
\text { assalariada. }\end{array}$ & $\begin{array}{l}\text { Mão-de-obra familiar e mutirão } \\
\text { (família envolvida na produção, } \\
\text { cooperativismo, associativismo e } \\
\text { coletivismo). }\end{array}$ \\
\hline Natureza do trabalho & $\begin{array}{l}\text { Trabalho alienado (exploração do } \\
\text { trabalho - o produto do trabalho } \\
\text { não pertence ao trabalhador) e } \\
\text { estranhado (o trabalhador não se } \\
\text { reconhece como parte do produto } \\
\text { final). }\end{array}$ & $\begin{array}{l}\text { Trabalho autônomo e familiar (o } \\
\text { produto do trabalho pertence a } \\
\text { família). Trabalho voltado para } \\
\text { auto-exploração e a possibilidade do } \\
\text { trabalho acessório. }\end{array}$ \\
\hline $\begin{array}{l}\text { Modelo de } \\
\text { desenvolvimento }\end{array}$ & 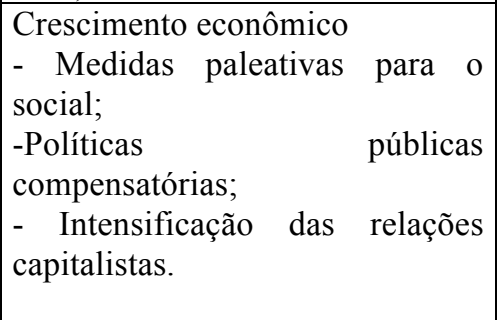 & $\begin{array}{l}\text { Desenvolvimento socioterritorial } \\
\text {-Reprodução social, econômica, } \\
\text { cultural e ambiental; } \\
\text { - Medidas para desconcentração de } \\
\text { terra e renda; } \\
\text { - Políticas públicas emancipatórias; } \\
\text { - Reprodução de relações não } \\
\text { capitalistas. }\end{array}$ \\
\hline Território/terra & $\begin{array}{l}\text { Expansão desenfreada } \text { em } \\
\text { grandes extensões de terras } \\
\text { segue a sanha capitalista de } \\
\text { apropriação da natureza } \\
\text { (metabolismo societário do } \\
\text { capital globalizado que gera } \\
\text { mazelas; trabalho análogo a } \\
\text { escravidão; superexploração } \\
\text { física e mental; expropriação } \\
\text { territorial; } \\
\text { territorial; monopolização } \\
\text { socioambientais: desmatamento, } \\
\text { poluição água, ar, solo etc.). }\end{array}$ & $\begin{array}{l}\text { Reprodução equilibrada em } \\
\text { pequenas propriedades baseadas em } \\
\text { um desenvolvimento socioterritorial } \\
\text { que respeita o social, cultural e } \\
\text { ambiental (relações sociais de } \\
\text { produção não capitalistas pautadas } \\
\text { no equilíbrio } \\
\text { sociobiodiversidade; na Soberania } \\
\text { Alimentar; na Educação do Campo; } \\
\text { na territorialização dos movimentos } \\
\text { socioterritoriais camponeses; na } \\
\text { simbiose entre produção de } \\
\text { alimentos e energia etc.). }\end{array}$ \\
\hline $\begin{array}{l}\text { Posições teóricas- } \\
\text { políticas-ideológicas } \\
\text { defendidas }\end{array}$ & $\begin{array}{l}\begin{array}{l}\text { Integração aos mercados } \\
\text { capitalistas (pela destruição ou }\end{array} \\
\text { monopolização do território), } \\
\text { formação de redes de relações } \\
\text { capitalistas, logísticas, preços e } \\
\text { tendências. Subordinação ao } \\
\text { capital nacional e internacional. }\end{array}$ & $\begin{array}{l}\text { Superação dos mercados capitalistas } \\
\text { (criação de territórios-mercado para } \\
\text { reprodução das relações não } \\
\text { capitalistas), o campesinato como } \\
\text { classe e modo de vida; reprodução } \\
\text { camponesa pela contradição } \\
\text { estrutural e pela luta, conflito, } \\
\text { disputas territoriais. }\end{array}$ \\
\hline $\begin{array}{l}\text { Sustentação teórica- } \\
\text { política-ideológica- } \\
\text { utópica }\end{array}$ & $\begin{array}{l}\text { Paradigma do capitalismo } \\
\text { agrário }\end{array}$ & Paradigma da questão agrária \\
\hline
\end{tabular}

Org. CUBAS, Tiago E. A. e CAMACHO, Rodrigo S. (2012).

O território não é somente um conceito, uma palavra, é um instrumento para entendermos os movimentos socioterritoriais, as dinâmicas do campo que revelam as relações sociais e de poder capitalistas e anticapitalistas. O anticapital (negação e resistência) não é ausência do capital ou do sistema capitalista, pois, isso é impossível, mas é a resistência, recriação e/ou retaliação a essa lógica, um território baseado em essência em outros elementos de reprodução baseada nas relações não capitalistas de (re)produção. 
Esse território do anticapital é o território comandado por relações sociais distintas das que se desenvolvem no território do capital, relações que desenvolvem a auto exploração, coletividade e equidade, não a (super)exploração, mais-valia, individualismo e segmentação social (LEFEBVRE, 1991; FERNANDES, 2008b e 2009). O território imaterial que propõe o anticapital é o que reproduz relações não capitalistas. O capital ignora as relações não capitalistas em sua análise (e procura englobá-las num discurso único), e se destaca então em apropriar tudo e todos; já o anticapital não ignora, mas procura questionar as suas incoerências. O sujeito social que territorializa relações não capitalistas cria a possibilidade de outras interpretações sobre a realidade e questiona a legitimidade do discurso capitalista.

\section{A TERRITORIALIZAÇÃO DO AGRONEGÓCIO E DO CAMPESINATO A PARTIR DOS INVESTIMENTOS DO GOVERNO FEDERAL BRASILEIRO ${ }^{5}$}

$\mathrm{O}$ agronegócio-latifundiário-exportador tem sido considerado o símbolo da modernidade no campo, mas esconde por trás da aparência moderna, a barbárie da exclusão social e expropriação dos povos do campo que sua concentração de terra e de renda provoca. Assim, entendemos que a agricultura camponesa e a dos povos tradicionais do campo possuem uma relação de equilíbrio com a natureza, fruto de sua prática da policultura orgânica, e porque entendem a produção de alimentos como requisito principal, pois, visa a transformação da natureza, primordialmente, como forma de sobrevivência e não como forma mercadológica de produção de capital (FERNANDES, 2008a e 2008c).

Vejamos o Gráfico 1 que expressa os investimentos na agricultura camponesa e na agricultura capitalista.

\footnotetext{
${ }^{5}$ Os dados disponibilizados e expostos nesse ponto foram dados coletados nos sites: do MDA (Ministério do Desenvolvimento Agrário); do MAPA (Ministério da Agricultura, Pecuária e Abastecimento); do Territórios da Cidadania; e da EMBRAPA (Empresa Brasileira de Pesquisa Agropecuária) - vide Referências bibliográficas.
} 


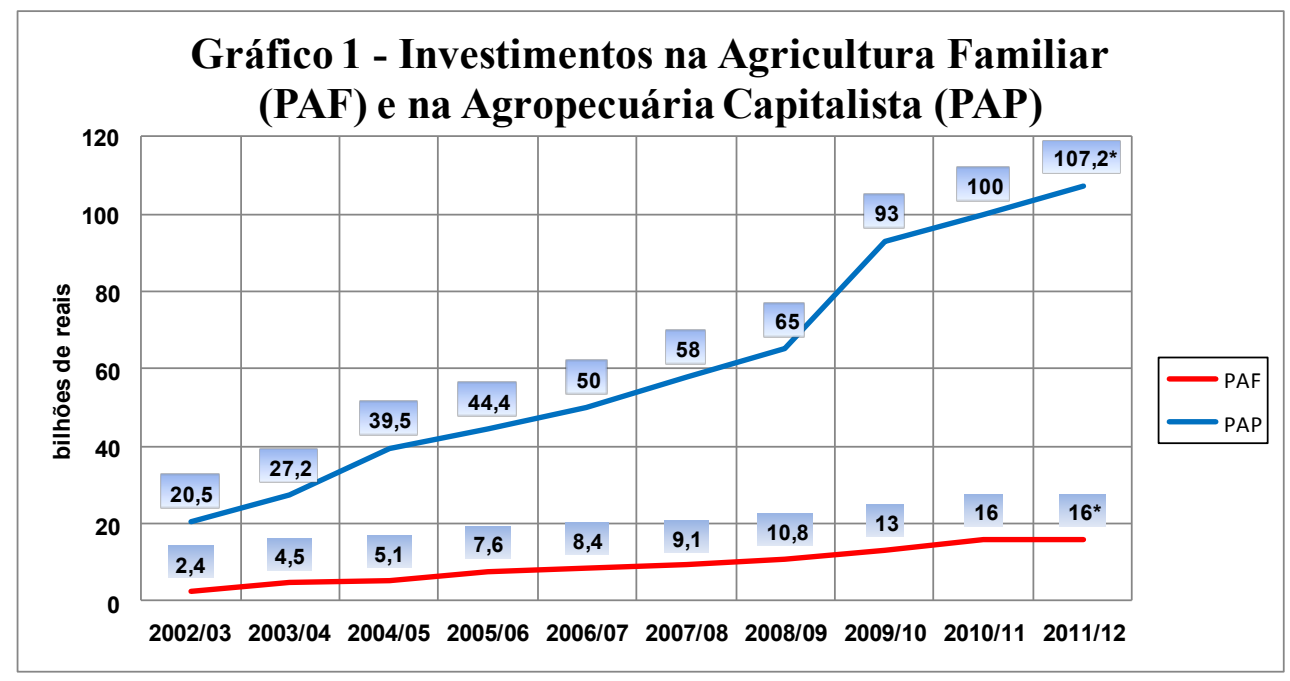

*Previsão de recursos para o PAF (Dados do PRONAF) e PAP 2011/12

Org. Tiago Cubas

Fonte: Elaboração própria a partir dos dados do Ministério da Agricultura, Pecuária e Abastecimento (MAPA) e do Ministério do Desenvolvimento Agrário (MDA).

Essas duas relações sociais antagônicas (campesinato e agronegócio) produzem territórios distintos, com paisagens e territorialidades distintas (FERNANDES, 2008a). Nessa perspectiva, podemos dizer que o cenário paulista reflete um país que busca concretizar as commodities, como a cana-de-açúcar em detrimento da produção de alimentos como arroz, feijão e milho. O Gráfico 1 comparativo entre os investimentos para o Plano Safra da Agricultura Familiar (PAF) e o Plano Safra da Agricultura e Pecuária capitalista (PAP) vai nos trazer elementos para embasar essa análise.

Dos planos de 2002/03 para os planos de 2010/11 tivemos tanto no PAF como PAP um aumento nos recursos direcionados para agricultura familiar ou camponesa e para agricultura capitalista. A divergência que podemos apontar ao interpretar os dados é que o aumento foi muito maior para os investimentos voltados para agricultura capitalista. De 2002/03 para 2010/11 o PAP aumentou seus investimentos cerca de R\$ 79,5 bilhões, e o PAF aumentou cerca de R\$ 14,6 bilhões. Apesar de, proporcionalmente, o crescimento ser semelhante, a diferença absoluta é significativa, isso aponta para o prevalecimento (dos interesses) do território do Paradigma do Capitalismo Agrário nas políticas públicas para o campo.

Para 2011/12 serão destinados no Plano Agrícola da Agricultura e da Pecuária $\mathrm{R}$ \$ 107,21 bilhões, isso revela um aumento de 7,2\% em relação ao plano passado. O que justifica o que dizemos até então é mostrar que segundo o Ministério da Agricultura (MAPA, 2011), essa linha de crédito tem a intenção de renovar os canaviais brasileiros, com destaque para o incentivo a própria cana-de-açúcar, além da laranja e da pecuária. 
Para esse plano não existe limite de crédito por estado, isso se dá por recursos oferecidos por linha de investimento, e são três: custeio e comercialização ( $\mathrm{R} \$ 80,2$ bilhões); investimento ( $\mathrm{R}$ 20,5 bilhões); e linhas especiais ( $\mathrm{R}$ \$ 6,5 bilhões).

Estava incluso no discurso de lançamento da presidenta Dilma Roussef, em Ribeirão Preto em 17 de junho de 2011, um incentivo especial à produção da cana-deaçúcar e a pecuária. Por isso, houve a criação de uma linha especial de crédito para a cana, por produtor, que será de um milhão de reais para expansão e renovação dos canaviais; e para a pecuária, por produtor, que será de 750 mil reais para compra de matrizes, produtores e custeio. Ou seja, além dos investimentos em custeio, comercialização e produção, teremos essa linha especial direcionada para uma maior expansão do agronegócio da cana e da pecuária brasileira e paulista.

Já para o Plano Safra do Agricultor Familiar de 2011/12, que é para o campesinato, temos um investimento total de $\mathrm{R} \$ 16,2$ bilhões. O foco desse plano é incentivar a produção de alimentos, os que principalmente fazem parte da alimentação tradicional do brasileiro como arroz, feijão, milho e mandioca. Um braço importante do Plano Safra do Agricultor Familiar é o PRONAF (Programa Nacional de Fortalecimento da Agricultura Familiar) que tem tido um aumento de repasse para os agricultores desde que foi criado e que incentiva a produção dos camponeses. Para o estado de São Paulo, no interior dos recursos destinados pelo PRONAF para o PAF foi direcionado o recurso de até $\mathrm{R} \$ 700$ milhões.

E além desses investimentos, temos o PAA (Programa de Aquisição de Alimentos). Este tem sido uma alternativa extremamente interessante para os camponeses paulistas que com subsídio do Estado fornecem seus alimentos para creches, escolas, hospitais, dentre outras instituições públicas. Um mercado diferente se concretiza com a proposta desse programa, pois, aqui o capital não se apropria do produto do trabalho camponês, o que permite a sua recriação de maneira menos subordinada ao capital. Comparativamente, vemos que a manutenção dos territórios capitalistas financiados pelos governos é cerca de $650 \%$ maior do que o investimento nos territórios camponeses. Contudo, o campesinato tem sido propositivo ao avançar no território das políticas públicas e nas lutas sociais. 


\section{TERRITÓRIOS E PARADIGMAS EM DISPUTA NA SOBERANIA ALIMENTAR: ALIMENTOS VERSUS COMMODITIES}

No processo de construção do conhecimento científico temos diferentes interpretações da realidade que formam conceitos, teorias, categorias, paradigmas, métodos, ideologias, etc., elementos que compõem a formação do pensamento científico. Essas diferentes leituras da realidade disputam a hegemonia do processo de avanço do conhecimento científico. Devido a essa disputa construída a partir da pluralidade de concepções existentes, podemos denominar esse conjunto de elementos que formam o conhecimento científico de territórios imateriais (FERNANDES, 2008b; 2009).

O território é marcado pelas relações de poder e pelas correlações de forças que estão implícitas e explícitas nas relações sociais. Assim, entendemos a Soberania Alimentar como um território que explicita leituras da questão agrária por meio do território material e também do imaterial, que não é somente uma analogia ao pensamento. O conceito de território carrega no seu interior noções como o poder, a ideologia, a disputa e o conflito. As manifestações, as ocupações, as políticas públicas, os agrishows, entre outros instrumentos dos movimentos socioterritoriais, das organizações patronais e do Estado territorializam os seus objetivos todos os dias e assim criam e recriam territórios imateriais, através do aparato simbólico, que por sua vez irão influenciar na consolidação/manutenção ou rompimento de uma determinada lógica nos territórios materiais.

Os Agrocombustíveis ou Agroenergia e a Soberania Alimentar são questões da atualidade no cenário nacional, isto porque existe uma possível mudança da matriz energética que acarreta mudanças na reestruturação agrário/agrícola do Brasil. Esta reestruturação traz severas implicações ao abastecimento de alimentos no Brasil e no mundo. Neste sentido, debater este tema é de fundamental importância no contexto atual. Segundo Fernandes (2010), a Soberania Alimentar passa a ser um exemplo de território, uma ideia que foi materializada em políticas públicas. Essas, por sua vez, quando passam a ser reproduzidas nos territórios materiais, mudam as relações anteriormente estabelecidas, gerando disputas e conflitualidades entre classes e modos de vida distintos. Em suas palavras: 
Tomamos a soberania alimentar como um exemplo de território, partindo de sua concepção como idéia materializada em política pública que muda as relações sociais, gera conflitualidades entre classes sociais e muda modos de vida. São idéias - territórios, que ao serem construídas carregam em si os princípios do espaço e das relações onde nasceu. Com este exemplo, procuramos demonstrar como os territórios estão presentes em nosso cotidiano e como é importante compreendê-los (Não paginado, grifo nosso).

O território é como uma parte do espaço que está sempre em disputa (para nós, disputas que vão do indivíduo a grupos que se realizam na luta de classes). A sociedade produz o espaço e, assim, o espaço é o lugar das relações sociais que envolvem a sua produção e a sua reprodução. O espaço é produto do trabalho humano em realidades físicas diversas, é o resultado da luta pela vida de indivíduos e grupos que se organizam em classes sociais para formar seus territórios. Toda relação social tem as dimensões espacial e temporal, dois elementos da realidade inseparáveis, assim um transforma o outro, produzindo infinitas misturas de realidades físicas e metafísicas.

Para que o território imaterial exista é inerente à existência do território material como uma base, pois, o imaterial não existe por si só, mas por uma complexidade de eventos, fatos e situações que formam o território como parte do espaço e o lugar de atuação do homem, onde se encontram as suas conflitualidades. Existe uma relação dialética entre os territórios materiais e os territórios imateriais, tendo em vista que na medida em que os territórios imateriais influenciam nas mudanças sociais, na formação das leis, nas políticas públicas, na direção da economia, etc. estes influenciam na formação de territórios materiais e na mesma medida, dialeticamente, o processo de construção/desconstrução/reconstrução de territórios materiais influenciam na construção/desconstrução/reconstrução de territórios imateriais. Pensamos, assim, que o território é sempre um espaço de lutas nas esferas política, econômica, social, cultural e até mesmo ideológica, por isso consideramos sua multidimensionalidade. O território é alvo de disputa tanto nos campos materiais como nos imateriais e, por isso, os conflitos existentes entre os conceitos do Paradigma da Questão Agrária e do Paradigma do Capitalismo Agrário. Conceitos esses que refletem no que entendemos sobre a "Segurança Alimentar" e a "Soberania Alimentar", ou seja, se torna necessário explicitarmos essas relações para não nos limitarmos à realidade capitalista. Enquanto no Paradigma do Capitalismo Agrário a Segurança Alimentar está relacionada à obrigação que o Estado capitalista tem de garantir o acesso da população aos alimentos, independente da forma como ocorre este processo. A Soberania Alimentar está ligada a 
autonomia dos povos enquanto um direito que os mesmos têm de produzirem seus próprios alimentos em seus territórios.

\begin{abstract}
É por esse referencial que se faz necessário discernirmos as diferenças entre segurança alimentar e soberania alimentar, antes que possíveis confusões possam ser construídas, pois quando apostamos na soberania alimentar não estamos apenas demarcando um campo de pesquisa ou mais uma nomenclatura para os próximos projetos, tampouco mais um conceito ou palavra chave. Então, para o momento é importante definir que enquanto a segurança alimentar tem a ver com a obrigação dos Estados nacionais em garantir o acesso aos alimentos em quantidades suficientes, sem se por em questão a origem dos mesmos, inclusive podendo contar com ajudas internacionais; a idéia e o conceito de Soberania Alimentar está erigido à partir da defesa do direito dos povos e dos países de definir suas próprias políticas e estratégias de produção de alimentos destinados ao abastecimento de sua população, antes mesmo da necessidade mercadológica e de exportação, como imperante e crescentemente marcado no cenário global (THOMAZ JR., 2007: 9, grifo nosso).
\end{abstract}

De acordo com João Pedro Stedile (2012) ${ }^{6}$, as políticas de Segurança Alimentar dizem respeito a aplicação de recursos com o objetivo de que as pessoas não passem fome. São exemplos de políticas integrantes da Segurança Alimentar: a merenda escolar, o bolsa família, a distribuição de cestas básicas etc. A Soberania Alimentar diz repeito ao conjunto de políticas que possibilitam o acesso das pessoas aos alimentos por meio de sua própria renda. No caso do campo, que os próprios povos possam produzir seus alimentos, no caso da cidade, que os trabalhadores possam ter acesso a alimentação por meio de sua própria renda.

Enquanto o agronegócio pode ser favorável a Segurança Alimentar, não tem como o mesmo apoiar a Soberania Alimentar, pois, sua lógica vai basicamente contra a reprodução da Soberania Alimentar. Para ser favorável a Soberania Alimentar o agronegócio teria que contrariar a sua própria essência. Dito de outra maneira:

Essa é uma questão que não tem como ser formulada desde o polo do capital (ser agenda do agronegócio) senão como farsa ou cinismo. Por isso também o capital pode admitir (em tempos de crise) discutir "segurança alimentar", mas não pode, sem trair a si mesmo, aceitar o debate acerca da "soberania alimentar" (pautado hoje pela agricultura camponesa). (CALDART et al., 2012:15, grifo nosso).

Essa diferenciação é fundamental para entendermos a importância de como a Soberania Alimentar é construída. Esse conceito é consubstanciado pela lógica do

\footnotetext{
${ }^{6}$ Informação verbal. Fala proferida durante o lançamento do livro: "Dicionário da Educação do Campo" que ocorreu no dia 10 de maio de 2012 na FCT/Unesp campus de Presidente Prudente.
} 
Paradigma da Questão Agrária, pois, o mesmo propõe uma política de desenvolvimento territorial rural que remete ao plano camponês e, por consequência, da agricultura camponesa. A produção de alimentos deixa de ser algo para ser resolvido de maneira imediata e paliativa, para algo que tem a necessidade de transformar a estrutura de todo o modo de produção. Substituindo a lógica mercadológica do agronegócio e no lugar desenvolvendo uma lógica social de não só abastecimento de alimentos a população, mas também de controle dessa produção de alimentos de modo que possibilite o fortalecimento da agricultura camponesa.

Assim, se torna uma questão de relevante importância para refletirmos é a Soberania Alimentar, ou seja, “a soberania alimentar é entendida como um princípio que define o direito e até o dever que cada povo tem de produzir os alimentos de que necessita para sua sobrevivência [...]”. (STEDILE, 2007: 42). A soberania alimentar é uma alternativa para a segurança alimentar. As discussões de soberania alimentar devem estar situadas nos âmbitos das comunidades locais e regionais, comparando com o que se faz a nível global. Dessa forma, se torna fundamental abrir essas discussões para as estratégias das diretrizes, com menos imposições, e isso poderia ocasionar oportunidade para quem deveria de fato falar, os agricultores, minimizando, assim, a subalternidade massiva contra os povos tradicionais e os movimentos socioterritoriais. A soberania alimentar para além da distribuição de alimentos se situa em dar qualidade à segurança alimentar, espacializar a distribuição nutritiva e equitativa dos alimentos, com pressuposto no olhar essencial para como se realizam e como podem se realizar os processos sociais e culturais. Por isso o conceito de soberania alimentar implica em entender que a lógica produção-consumo passa por valores sociais, culturais e ambientais fundamentais para constituírem uma sociedade que também tem renda e poder desconcentrado.

Quando os governos nacionais aderiram à OMC em 1995, eles abandonaram seus poderes para definir unilateralmente a sua própria comida e políticas agrícolas. As exigências da OMC causaram uma grande reestruturação baseada na segurança alimentar e programas de subsistência rurais dos países em desenvolvimento, mas o principal efeito de trazer agricultura na OMC não era somente reformar a agricultura global em linha com racionalidades do mercado, mas agravar as já existentes oportunidades desiguais no sistema mundial de alimentos (WITTMAN, 2011, p. 90).

Segurança é pontual no direito de se alimentar, não importa a origem e o processo, a soberania é territorial, é controle "nativo" da comida produzida pelo povo e 
para o povo. A soberania alimentar é um conceito (uma teoria para Wittman (2011)) que vem da sociedade civil, é o poder legitimamente emanando de baixo, esse conceito engloba bases econômicas, sociais e ambientais. Os processos são aí fundamentais para entendermos como se produz alimentos e energia de modo equilibrado vislumbrando desenvolvimento social.

Para tanto, o conceito de sistema agro-alimentar corporativo e do avanço do capitalistamo agrário é uma chave para abrir não somente os momentos estruturais e transições históricas das relações capitalistas sobre os alimentos, mas também da história do próprio capitalismo. Esse regime alimentar é uma ótica importante sobre as múltiplas determinações incorporados no produto alimentar, como um gênero fundamental para a história capitalista. "Como tal, o conceito de sistema agro-alimentar nos permite recentrar da commodity como objeto para a commodity como relação, em definitivo relações geo-políticas, sociais, ecológicas e nutricionais que refletem em importantes momentos históricos" (MCMICHAEL, 2009, p. 163). A commodity então é estabelecida como uma relação social dos ruralistas para a sociedade. De um lado os produtores e de outro os consumidores, respectivamente a oferta e a demanda da produção e do consumo nas interfaces da utilização de energia, água e recursos financeiros e naturais.

A cientista social Hannah Wittman (2011) fala então da teoria sistema-mundo, questionando onde se situa o local nesse sistema e quais as relações de poder que estão envolvidas e involucradas na formação desse sistema-mundo. O sistema-mundo então, sinteticamente para ela, é composto pelo core, ou o centro econômico-financeiro e na sua contraposição está a periferia, onde os recursos naturais estão sendo (ou já foram) super-explorados, e a transição dessas relações são as semiperiferias, os lugares onde acontecem os dois processos ao mesmo tempo. Bens agregados partem do fluxo "core" para "periferia", e no fluxo contrário estão o fornecimento de mão-de-obra e matérias primas. Por isso, as relações de comércio, as relações de exploração humana e do meioambiente, e a dívida ecológica são elementos importantes para apreender esse sistemamundo. O capitalismo se desenvolve a custas dos recursos existentes (e dos que já existiram e se transformaram em produtos).

O imperialismo ecológico se estabelece como a nova forma de dominação do capital vinculada à necessidade das relações comerciais entre países do core com os países da periferia, isso através da imposição cultural e econômica no que tange ao modo de construir a paisagem, e também ao esgotamento das matérias primas em seus 
países. Nessa perspectiva, esse imperialismo se dá na invasão indiscriminada das terras e dos recursos dos países da semiperiferia e da periferia. O investimento externo nesses países provoca o que conhecemos como o conceito de estrangeirização das terras, ou seja, é o poder disseminado no controle de terras, na procura de investir onde o custo é menor atrelado aos subsídios estatais desses países de "semiperiferia" ou "periferia".

O discurso inicial do imperialismo ecológico é a necessidade da futura produção alimentar para segurança alimentar, entretanto, a grande maioria das áreas onde essas transnacionais se instalam se verifica um alto grau na produção de commodities. "Esta definição de segurança alimentar trata de alimentos como um problema de insuficiência do comércio eficiente ao invés de fome, ao privilegiar o acesso a alimentos em vez de controle sobre os sistemas de produção e consumo" (WITTMAN, 2011, p. 91), nesta concepção, “o alimento é uma mercadoria negociável e não um direito, a fome é simplesmente um problema de distribuição" (p. 5).

Um sistema estrutural de comércio baseado na injustiça global, em que os custos ambientais e sociais da extração de recursos não são suportados pelos consumidores e repassado aos agricultores camponeses (desde a produção ao consumo, as pessoas que participam dessas interfaces distintas do processo produtivo se distanciam da realidade e não comungam dos elementos de composição estrutural das relações de trabalho e de poder). A externalização dos dividendos do imperialismo ecológico fica relegada aos produtores e ao lugar onde se produz. O ônus é totalmente abatido na vida dos trabalhadores urbanos e rurais, esse prejuízo não se coloca no bolso dos capitalistas e muito menos na sociedade consumidora que, alienada, não "faz parte" dessa realidade, e se chega, chega como reajuste de preços, a ficcional "inflação". A exploração do outro (não importa o quanto) sempre tem um preço nessa lógica.

O debate da Soberania Alimentar se mostra fundamental, principalmente na atualidade, em que começa a ficar mais rentável plantar para a produção de agrocombustíveis, ao invés de plantar para a produção de alimentos. Essa inversão de prioridades ocorre porque a produção agrícola para o capitalismo e, consequentemente, para o agronegócio, não passa de mais uma mercadoria, onde o alimento também se torna mercadoria, cuja produção depende do retorno financeiro que esse "negócio" dará. Porém, entendemos que a alimentação é a primeira necessidade humana, e, logo, é a primeira função do trabalho na transformação da natureza. Por isso, ela é a prioridade para os camponeses e todos os povos do campo, mas quando os camponeses são desterritorializados ocorre a perda da Soberania Alimentar. 
Para percebermos essa inversão de prioridades, concomitantemente ao que acontece atualmente no país, temos o Gráfico 2 que legitima essa lógica de mercado e lucro máximo. A propriedade no agronegócio tem que ser otimizada em detrimento histórico da expropriação da população rural no Brasil. $\mathrm{Na}$ medida em que o agronegócio se territorializa menos pessoas temos no campo. A marca do agronegócio é o campo sem gente.

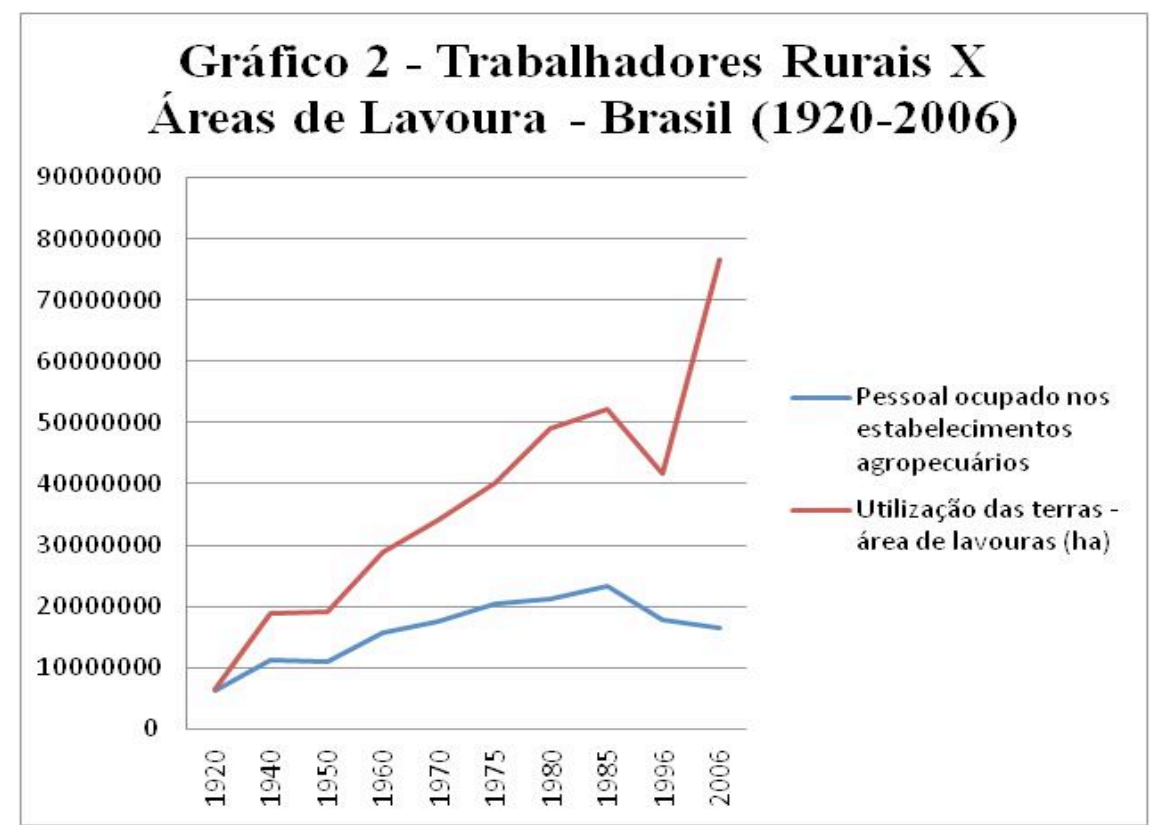

Fonte: IBGE, 2010. Org. Tiago Cubas e Federico Sulroca.

Aspecto importante a ser destacado é que enquanto o latifúndio expropria pela improdutividade, o agronegócio expropria pela altíssima produtividade (FERNANDES, 2009), mas o que podemos compreender nessa análise é que nos dois modelos temos notado o êxodo de pessoas no campo. Esse êxodo de trabalhadores rurais é observado quando nos pautamos na realidade do controle (do território) fundiário, pelo "coronel" no latifúndio, e por empresários com alto grau de mecanização nos territórios do agronegócio, isso reflete numa questão agrária brasileira de alta concentração fundiária e de poder.

Então, o que fundamenta a nossa visão de Soberania Alimentar voltada para o subsídio da agricultura camponesa é o próprio cenário brasileiro. Esse cenário reflete um país que busca concretizar as commodities, como a cana-de-açúcar e a soja, que estão em larga expansão no país. Podemos notar a expressão do debate que pretendemos levantar quando falamos da Soberania Alimentar como algo fundamental para soberania nacional, como podemos visualizar na Figura 1. 
Figura 1 - Reflexos dos paradigmas na agricultura brasileira: agrocombustíveis e alimentos

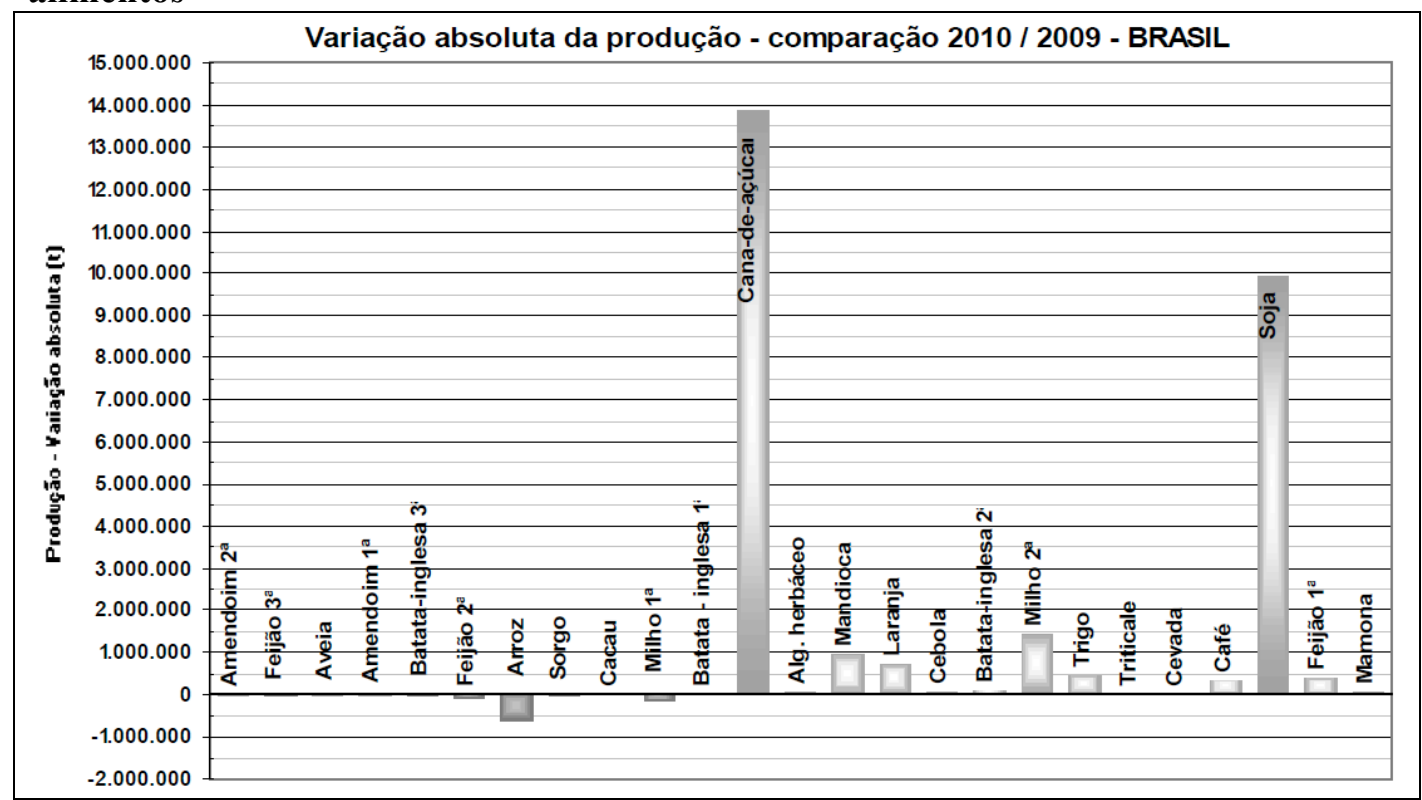

Fonte: IBGE, 2010.

A partir disso, visualizamos a situação que se encontra a disputa territorial entre os paradigmas do Capitalismo Agrário (representado no agronegócio) e o da Questão Agrária (representado na Soberania Alimentar). Esse é um espaço de luta política e ideológica que no Paradigma do Capitalismo Agrário reforça a dominação e expansão das comoditties, e no Paradigma da Questão Agrária legitima a luta pela Reforma Agrária, Soberania Alimentar e Justiça Social. A cana-de-açúcar (14 milhões de toneladas) e a soja (10 milhões de toneladas) são produtos de exportação e destaque de produção do agronegócio, em detrimento dos alimentos como o arroz, o feijão, o milho e a mandioca que estão numa amplitude de variação absoluta negativa para positiva com no máximo de 2 milhões de toneladas. Isso reforça o que foi exposto sobre o cenário nacional da agricultura brasileira: a expansão do território do agronegócio, para as comoditties, e a redução da produção de alimentos que é colocada em segundo plano pelas políticas públicas.

Portanto, entendemos que é a agricultura camponesa que deve ser a prioridade das políticas públicas e não o agronegócio. Corroborando com nossa análise, Stedile afirma: "o alimento é um direito de todos os seres humanos e não mera mercadoria da qual se busca extrair lucros [...]”. (2007: 42). Logo, a produção agrícola camponesa baseada na policultura, é essencial para manter a Soberania Alimentar. 
A produção de alimentos é uma característica fundamental do modo de vida camponês (SHANIN, 1983). Para o camponês, a comida é o elemento central da produção e do consumo que são realizados na interdependência entre terra, família e trabalho, pois, expressa uma moral entre os homens e deles com a natureza. A troca e a reciprocidade entre os iguais divergem da lógica do negócio, da compra e venda do capitalismo (WOORTMANN, 1990).

A comida significa em primeiro lugar a reprodução material camponesa, todavia, sua importância ultrapassa a sua materialidade. A relação da comida, com a terra, o trabalho e a família é a seguinte: a comida é a fonte de reprodução familiar conseguida por meio do trabalho na terra. É por meio da produção de alimentos também, que se estabelecem laços de solidariedade e de sociabilidade com a comunidade. De uma maneira simbólica, ao oferecer os alimentos de sua produção a outros, se estabelecem vínculos com aqueles a quem considera (ALMEIDA; PAULINO, 2010).

Para pensarmos a produção camponesa, temos que pensar em primeiro lugar na produção da comida. Como relata Aloísio, militante do Movimento de Pequenos Agricultores, “[...] a gente tem produção de leite, frutas, café, mel de abelha, inserindo também agora peixe né, tamo querendo trabalhar com galinha caipira também, enfim, pra diversificar a renda da família e sair da lógica do monocultivo né”. (jul. 2010).

\section{A EXPERIÊNCIA DO MPA (MOVIMENTO DOS PEQUENOS AGRICULTORES) EM FREDERICO WESTPHALEN (RS): A RECRIAÇÃO POLÍTICA E CULTURAL CAMPONESA ATRAVÉS DA PRODUÇÃO DE ALIMENTOS E ENERGIA}

"não podemos produzir em forma de monocultura de maneira nenhuma. A diversidade da produção sempre foi esse legado histórico do camponês. Então, isso nós temos que manter". (ENNIO, militante do MST, jul. 2010).

Observando essa estrutura agrária-agrícola nacional, na visão do Paradigma da Questão Agrária, temos a situação/problema do campo brasileiro, e também a relação cidade-campo, dentro uma lógica estrutural. Partimos do princípio de que as relações sociais são mediadas pelo poder. Este poder pode ser do capital que cria e destrói os 
territórios, mas também temos a contradição dialética desse poder que está na (re)criação do território do não-capital, por exemplo, com a luta camponesa pela conquista de seus territórios. Dessa forma, a problemática central não está na conjuntura, ou nas relações camponesas, mas nas relações capitalistas que visam, fundamentalmente, o economicismo, ou seja, o crescimento econômico de uma minoria em detrimento de um planejamento territorial rural voltado para o desenvolvimento socioterritorial da maioria da população.

Após entendermos os novos fatores que compõem a questão agrária brasileira e as disputas territoriais que estão acontecendo na sua atualidade, refletimos acerca da importância de termos em mãos novos modos de recriar o espaço camponês, principalmente na condição em que as relações não capitalistas sejam recriadas no território. Então, fomos a campo a fim de estudarmos uma nova experiência articulada pelo MPA (Movimento dos Pequenos Agricultores), que traz a agroecologia e a soberania alimentar inerentes ao desenvolvimento territorial rural como pontos fundamentais para reprodução do território camponês.

O MPA é um movimento camponês, que tem um caráter popular e de massas. Sua base social é organizada em grupos de famílias nas comunidades camponesas. Esse movimento busca resgatar a identidade e a cultura camponesas na sua diversidade, dialogando com outros movimentos sociais em busca da construção de uma sociedade socialista (GÖRGEN, 2012).

O MPA é um movimento socioterritorial que surgiu do interior do MST, não como uma dissidência, mas como um movimento com características distintas, sendo os dois movimentos integrantes da Via Campesina. Enquanto o MST tem a função principal de destruir territórios capitalistas e construir novos territórios, o MPA tem a função de auxiliar na permanência do campesinato nos seus territórios evitando que sejam destruídos pelo capital. Partindo desse aspecto, poderíamos pressupor que são movimentos que tem em sua essência a composição organizacional semelhante, mas as estratégias de reprodução, de fato, são distintas, além de parte da estrutura desse movimento ser diferenciada. Observemos as diferentes estratégias de ação desses movimentos em que o território está situado na essência dessa luta.

Tanto o MST Nacional, quanto o MPA em Frederico Westphalen (FW), tem quatro pilares principais como base: organicidade (direção nacional e estadual), formação política (base), produção (organização produtiva) e a luta (manifestações e ocupações). É por meio desses quatro pilares fundamentais que se sustenta a lógica de 
atuação desses movimentos socioterritoriais. E, é por meio dessa lógica, que podemos observar, também, o território de atuação de cada um desses movimentos. A conquista de territórios, os assentamentos, é o principal alvo do MST. O MST, em síntese, parte de uma luta que se realiza por manifestações e ocupações com a intenção de pressionar o governo pela Reforma Agrária, ou seja, existe na sua essência uma busca pelo território (FERNANDES, 2000), além da perspectiva de ruptura com a lógica capitalista vigente.

A realidade da estrutura fundiária na região noroeste do Rio Grande do Sul região de 63 municípios onde a Cooperbio (Cooperativa de Produção de Biocombustíveis) atua - é baseada na pequena propriedade, como pode ser notada no Gráfico 3, onde as propriedades de 1 a 50 hectares representam, aproximadamente, $90 \%$ dessa distribuição total de imóveis rurais.

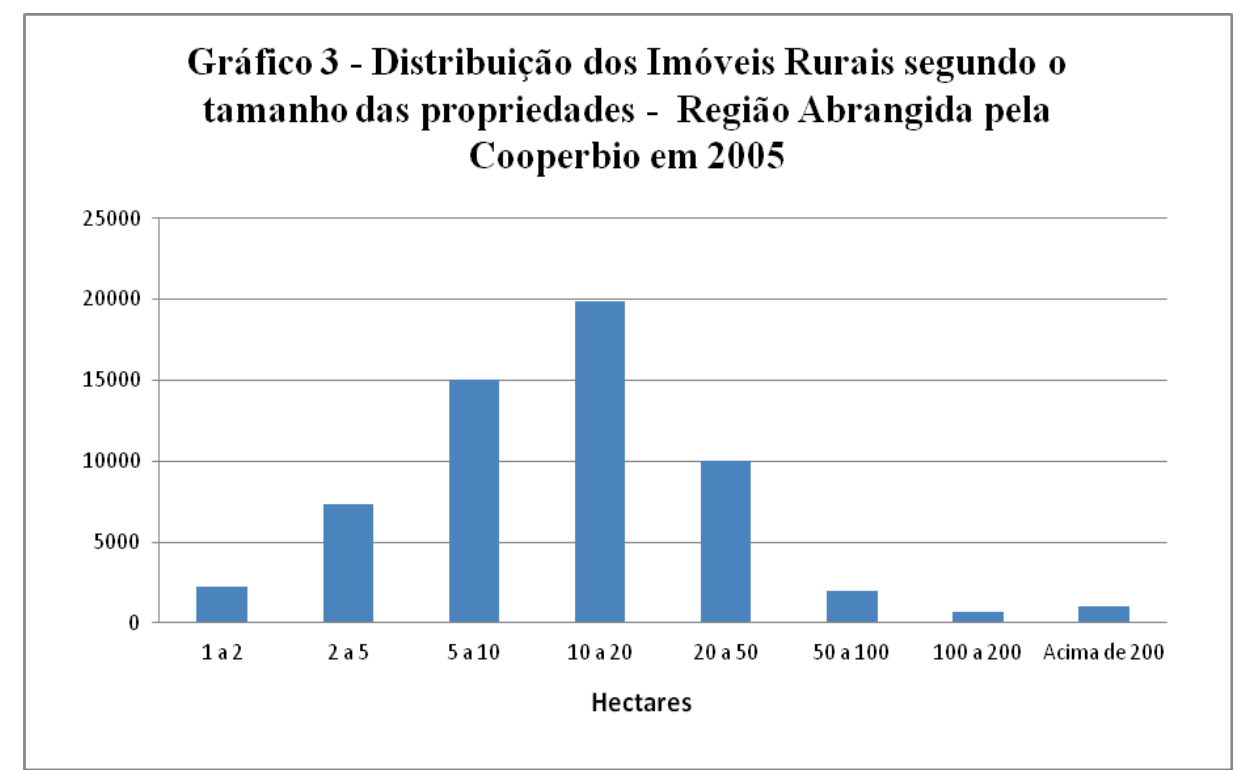

Fonte: IBGE, 2005. Org. MPA, 2007.

O processo de colonização que tivemos no Rio Grande do Sul, a partir das famílias de origem europeia, desemboca na divisão do território em pequenas propriedades na região noroeste do estado, e isso influenciou a construção de outro tipo de luta (LEAL, 2007). São 58 mil propriedades agrícolas com até 100 hectares, e essa configuração territorial se desdobra na luta na terra. A relação território-mercado está muito mais sensível nessa conjuntura, pois, as famílias já tem a terra e precisam de estratégias para garantir o uso e ocupação do seu território de forma digna e que permita continuidade da vida ali. 
Essa luta está relacionada à resistência e manutenção da propriedade camponesa, com vistas à produção de Alimentos e Energia no território camponês. Mas, também aparece fortemente no âmbito imaterial do próprio território, que é a disputa por políticas públicas que viabilizem o Plano Camponês ${ }^{7}$. Além dessa disputa pelas políticas públicas, o MPA atua na tentativa de conscientizar essas famílias do processo destrutivo para o campesinato que é a reprodução da lógica capitalista, construindo outro modelo de produção para manter as características da pequena propriedade camponesa com objetivo focado para a Soberania Alimentar ${ }^{8}$. O Plano camponês está assentado em dois pilares fundamentais: o primeiro é a garantia das condições para se viver no campo e o segundo são as condições para produzir no campo:

O Plano Camponês tem dois pilares fundamentais: 1) condições para viver bem no campo (educação camponesa, moradia digna, espaços de esporte, lazer e cultura, saúde, vida em comunidade etc.); 2) condições para produzir comida saudável, respeitando a natureza, e para alimentar o povo trabalhador (crédito, assistência técnica, mecanização camponesa, sementes crioulas, comercialização, seguro agrícola, apoio para agroindústrias etc.). (GÖRGEN, 2012: 495).

Desse modo, "a produção de alimentos e culturas para produção de agrocombustíveis, de forma agroecológica, também é uma experiência em desenvolvimento pelo Movimento dos Pequenos Agricultores [...]" (FERNANDES; WELCH; GONÇALVES, 2011: 10). Para nomear essa experiência, o MPA criou um termo: "ALIMERGIA". A partir desse paradigma, o movimento tem como principal meta: a produção de Alimentos e Energia, com Respeito ao Meio Ambiente, no interior do modo de produção camponês, entendendo o mesmo como uma célula, parte de um território, que tem relação com o todo (LEAL, 2007).

O plano camponês, baseado no conceito de ALIMERGIA, revoluciona com os pressupostos sociais vigentes no modo de produção e apropriação capitalista. A soberania alimentar passa a ser um conceito que participa concomitantemente com energia e reprodução do modo de vida camponês. Para esses camponeses, a soberania

\footnotetext{
7 O projeto original é o "Plano Camponês de Desenvolvimento". Esse Projeto surgiu após um longo debate em Brasília, feito entre integrantes do MPA e estudiosos do tema que foi realizada entre 2004 e 2006. Desembocou num estudo sobre o campesinato no Brasil e um plano propositivo para o desenvolvimento territorial rural (um dos pontos principais para esse desenvolvimento era a Organização de Produção desvinculada da lógica do agronegócio).

${ }^{8}$ Esses dados são fruto: da reunião com Romário Rosseto, Marcelo e Débora, membros da Direção Nacional e Estadual do MPA, em Frederico Westphalen (RS), nos dias 23 e 26 de março de 2010; e do trabalho de campo nos dias 24 e 25 de março de 2010, nos municípios de Frederico Westphalen (RS) e Caiçara (RS), para observar a estrutura da CooperBio e essa nova experiência camponesa.
} 
alimentar assevera que cada país tem o controle sobre o tipo de produção seja priorizada para sua população, de modo conjunto a produção agroecológica. É fundamental estabelecer a crítica na questão do desequilíbrio entre as necessidades da população e o que realmente se produz, onde se consome e quem ganha com essas amarras. Quando 45\% da produção global em 2012 foram desperdiçadas, o que precisamos não é produzir mais, mas distribuir melhor, direcionar recursos para alimentos, além de planejar de maneira mais eficaz (WITTMAN, 2011).

\begin{abstract}
Métodos de produção sustentáveis e ecologicamente corretos, o movimento da soberania alimentar tem suscitado um interesse crescente em agroecologia, como uma abordagem multifuncional para produção de alimentos, que incorpora prestação sustento, conservação da biodiversidade e do ecossistema e do bem estar da comunidade. Com base na teoria da relação inversa entre o tamanho da propriedade e a produção agrícola total (Altieri 2009, 2010; Ishii-Eiteman 2009; Rosset 2008, 2009a), os proponentes da pequena escala no modelo de produção agroecológica de alimentos argumentam que a diversidade, aproveitamento social e ecológico pode levar a uma maior produtividade e resistência a vulnerabilidade social-ecológica e às mudanças climáticas. [...] A agricultura multifuncional existe para produzir certos serviços ecológicos com mais eficiência do que os sistemas de monocultura. Além disso, um estudo importante por Badgley et al. (2007) mostrou que os métodos de produção agrícola orgânica, vem exigindo maiores entradas de trabalho para produção de alimentos suficientes para satisfazer as necessidades alimentares atuais sem expandir a terra agrícola.A recente da literatura sobre agroecologia e o direito à alimentação (Nações Unidas, 2010) sugere que os pequenos agricultores podem dobrar a produção de alimentos dentro de uma década em regiões críticas usando métodos de produção agroecológica e pesquisas de biodiversidade agrícola indicam que a base do conhecimento agricultor indígena contribui para a segurança alimentar. (p. 95).
\end{abstract}

O papel do camponês é fundamental na manutenção da vida do outro, porque ele produz para soberania alimentar e seu modo de vida produz equilíbrio social. Essa questão do desperdício levanta ao debate os aspectos relacionados à reordenação de hábitos alimentares; no que se refere aos aspectos nutritivos; a preservação cultural de produção e incorporação de novas técnicas; esquemas de circulação, fluxos e escoamento de produção e consumo; apropriação do produto pelo mercado; e especialmente, a reestruturação fundiária e de distribuição de riquezas e alimentos. “[...] A abordagem baseada em direitos que está incorporada na soberania alimentar é uma instituição explicitamente moral que está em contraste com os processos econômicos da globalização impulsionada pelo mercado" (WITTMAN, 2011, p. 92). Essa 
responsabilidade recai sobre o direito dos povos a construir, ou minimamente debater, as políticas públicas e fomentos necessários.

Frei Sergio Antonio Görgen explica que existe um antagonismo no campo com relação à produção de agrocombustíveis. Enquanto no agronegócio a produção de agrocombustíveis coloca em risco a Soberania Alimentar, pois, leva a uma competição entre a produção de alimentos e de agroenergia, a produção camponesa com seu projeto de alimergia combina produção de alimentos e energia com proteção ao meio ambiente, por meio de uma produção diversificada e consorciada. Em suas palavras:

No Brasil, há dois modelos antagônicos de produção de agrocombustíveis: 1) o do agronegócio, de produção em grande escala e com a terra organizada em latifúndios, concentrando riqueza, com cada vez maior controle das empresas transnacionais, com monoculturas de cana e soja, gerando pobreza e fome, sem sustentabilidade ambiental e criando uma competição inaceitável entre produção de alimentos e energia; 2) o da agricultura camponesa, voltado para a soberania alimentar e energética das comunidades camponesas, combinando produção de alimentos e energia com proteção ao meio ambiente (alimergia - alimento, meio ambiente, energia), com produção diversificada e consorciada e sistemas industriais de multifinalidades, de pequeno e médio porte, descentralizados. (2012: 54, grifo nosso).

A alimergia é um novo conceito que implica na defesa simultânea da Soberania Alimentar e Energética a partir da formação de agroecossitemas complexos de maneira integrada e harmônica aos ecossistemas locais. Este conceito representa um novo paradigma necessário para responder as necessidades humanas alimentares e energéticas no período atual.

Alimergia é um novo conceito em agricultura, pecuária e floresta que procura desenvolver formatos produtivos que integrem, de maneira sinérgica, a produção de alimentos e de energia com a preservação ambiental. A alimergia visa à soberania alimentar e energética das comunidades e dos povos de maneira integrada e harmônica com os ecossistemas locais. [...]. Porém, a alimergia não é apenas um novo conceito que procura unir, em um processo produtivo integrado e sistêmico, alimentos, meio ambiente e energia. É um novo paradigma, necessário para responder aos desafios e às exigências objetivas que a comunidade humana e a sobrevivência da vida da biosfera colocam em termos energéticos, alimentares e ambientais para o presente e, dramaticamente, para a construção do futuro. (GÖRGEN, 2012: 54, grifo nosso).

A seguir observemos a Figura 2 que ilustra o que compreende a estrutura da Cooperbio e como se porta essa nova experiência camponesa de produção. Estrutura 
essa que é formada, e visualizada na Figura 3, por: Agrofloresta (interação floresta e culturas da alimergia), Floresta Energética (cultivo diversificado de culturas necessárias para a produção de energia que movimenta as micro destilarias), Micro-Destilarias e Produção agrícola diversificada (policultura). Formando assim, os agroecossitemas camponeses e a lógica camponesa de produção de alimentos e energia de forma integrada. A Cooperbio é responsável apenas pela produção e a CPC (Cooperativa de Produção Camponesa) realiza a parte de mercado.

Figura 2 - Comparação entre os modelos de Produção Tradicionais e a Cooperbio

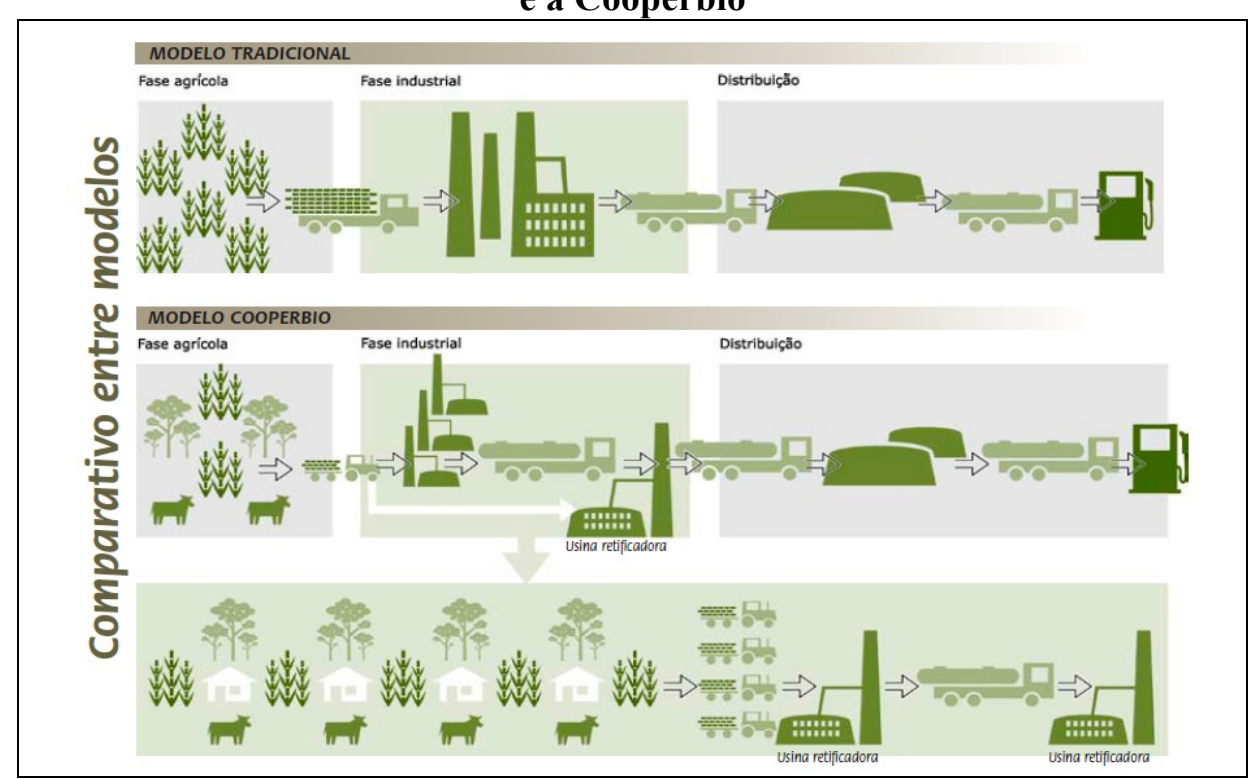

Fonte: MPA, 2007.

Figura 3 - Experiências da Produção Camponesa em Frederico Westphalen/RS e Caiçara/RS

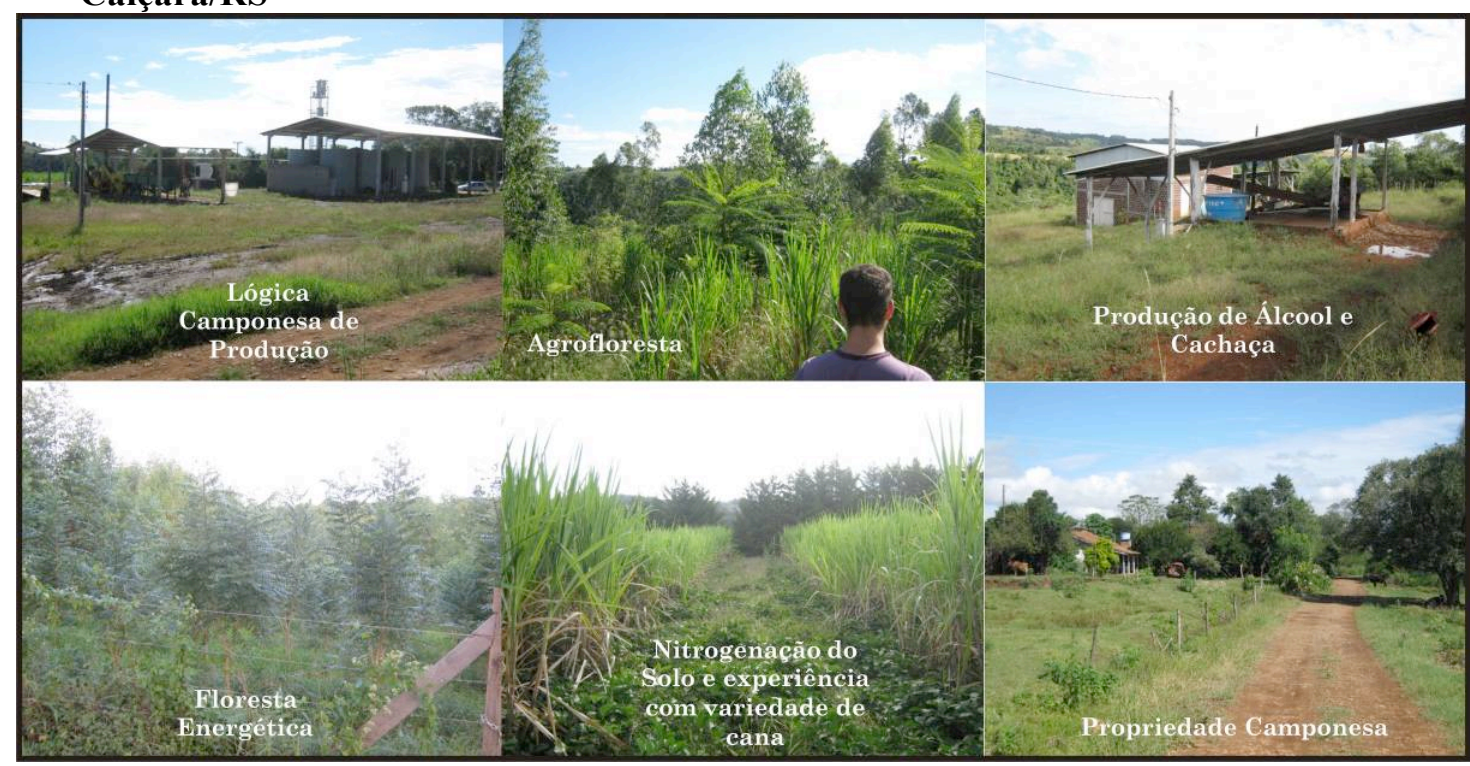

Fonte: Trabalho de Campo em Frederico Westphalen/RS e Caiçara/RS.

Org. Tiago E. A. Cubas. 
As micro destilarias podem trabalhar com a produção diversificada e o manejo em forma de um ciclo que procura degradar menos possível a natureza, com alta taxa de renovabilidade. A produção pode ser voltada para a cana-de-açúcar, batata doce, mandioca e sorgo sacarino. Essas micro destilarias ainda são capazes de produzir açúcar mascavo, melado, rapadura, cachaça, ração animal, adubo orgânico e álcool. Trabalhando também com sistema de moenda móvel ou fixa.

A Cooperbio é composta por aproximadamente 800 famílias que, além disso, também compõem o MPA, que traz a discussão política e ideológica desse levante e manutenção do modo de produção camponês. Essa cooperativa, conjuntamente com o trabalho que o MPA faz nessa região do estado do RS, tem desenvolvido um modelo agroecológico de produção. Modelo esse que tem como principais contribuições: o manejo sustentável do solo, a diversificação da matriz produtiva regional, o manejo de recursos naturais e uma agroindustrialização a favor da reprodução do território/territorialidade camponesa (LEAL, 2007).

Entendemos que essa nova lógica produtiva que vem sendo implantada em Frederico Westphalen, e assim por diante no noroeste do RS, é algo válido como uma semente que pode gerar frutos importantes para uma reprodução do território camponês. Contudo, vislumbramos também a relação território-mercado que é fundamental para que esse Plano Camponês e para que o desenvolvimento de novas práticas não capitalistas no território sejam eficazes e efetivadas. No território, mediado pela reprodução do capital, observamos essa intervenção desde a produção até o consumo, e isso passa pelos meios de escoar a produção e, principalmente, pela lógica de mercado (OLIVEIRA, 2004). Então, propomos ao debate de que isso também seja pensado, pois, as experiências de produção que são válidas, como a que o MPA tem realizado, necessitam de pesquisa e de novas soluções para que no final do processo de organização produtiva do camponês não venha cair novamente na lógica de mercado capitalista. Portanto, tem-se a necessidade de pensarmos em mercados alternativos para a produção camponesa, consolidando a relação de territórios não capitalistas com esse mercado. 


\section{CONSIDERAÇÕES FINAIS}

Os territórios se formam e se codeterminam a partir das relações humanas mediadas pelas relações de poder vislumbradas nas correlações de força. O território só existe a partir das relações humanas, das ações humanas no espaço e no tempo que se desdobram - através das suas vontades realizadas ou reprimidas, legitimadoras ou emancipatórias - no conteúdo e na forma territorial. Por isso, os interesses antagônicos que estão no seio da luta de classes se des-re-territorializam de maneira multiescalar e multiforme. Esses interesses perpassam do indivíduo ao Estado (RAFFESTIN, 1993), passando pelas classes sociais, e territorializando suas vontades nos campos da economia, cultura e política refletindo de fato no ambiente social.

A luta de classes não é somente uma luta física, mas também é metafísica, transcende o material e acontece também no âmbito imaterial através dos paradigmas (visões de mundo que se territorializam em ações individuais e coletivas). Os paradigmas refletem ideologias distintas que disputam territórios no espaço das ideias, disputam conceitos, disputam projetos, disputam políticas e, por isso, também disputam a realidade. Dessa forma, a maneira como construímos a realidade e a partir de que instrumentos e estratégias a construímos, explica que interesses estão desenhando de fato o território e qual a intencionalidade ali explícita ou implícita podemos visualizar.

Nos distintos territórios da luta de classes temos o território de relações capitalistas que reflete o Paradigma do Capitalismo Agrário (PCA) e os territórios de relações anticapitalistas que reflete o Paradigma da Questão Agrária (PQA), que disputam, conceitualmente, segurança alimentar versus soberania alimentar, desenvolvimento sustentável versus diversidade produtiva, biocombustíveis versus agrocombustíveis, agricultura/empresa familiar versus agricultura camponesa, por fim, produção capitalista versus produção camponesa.

A proposta então desse trabalho foi abordar a construção da vertente paradigmática que se desdobra na realidade das disputas territoriais materiais e imateriais. Contribuindo, assim, para um debate do contra discurso da legitimação do território camponês por meio da construção conceitual, que evidencia as disputas territoriais e a luta de classes a partir da realidade concreta da construção do território camponês no exemplo frutífero da cooperativa criada pelo MPA (Movimento dos Pequenos Agricultores), em consonância com os pequenos produtores da região de Frederico Westphalen (Rio Grande do Sul - Brasil). 
Os territórios camponeses são exemplos da recriação de relações sociais não capitalistas no capitalismo com base principal na produção de alimentos para o sustento da família e a venda do excedente para o restante da sociedade. Entendemos a agricultura camponesa como sendo a principal forma de garantir a Soberania Alimentar. Este é um conceito pautado teórico-política-ideologicamente no Paradigma da Questão Agrária, e a partir desse paradigma defendemos a necessidade de superação do capitalismo por seu caráter irreformável e incontrolável (MÉSZÁROS, 2005; 2007).

A Soberania Alimentar e a Soberania Energética são propostas defendidas por um movimento socioterritorial camponês ligado a Via campesina, o MPA. Esse exemplo demonstra a atitude propositiva dos movimentos camponeses. Não basta defendermos a destruição das relações capitalistas e a territorialização do agronegócio no campo, é necessário propor um modelo alternativo a esse modelo que entendemos ser pautado na exploração insaciável do ser humano e da natureza.

\section{REFERÊNCIAS BIBLIOGRÁFICAS}

ABRAMOVAY, Ricardo. Paradigmas do capitalismo agrário em questão. Campinas: Hucitec/Unicamp, 1992.

ALMEIDA, Rosemeire Aparecida de. (Re) criação do campesinato, identidade e distinção: a luta pela terra e o habitus de classe. São Paulo: UNESP, 2006.

. O conceito de classe camponesa em questão. Revista Terra Livre, São Paulo: AGB, ano 19, v. 2, n.21, p. 73-88, jul./dez. 2003.

; PAULINO, Eliane Tomiasi. Fundamentos teóricos para o entendimento da questão agrária: breves considerações. Revista Geografia, Londrina, v.9, n.2, p. 113-127, jul./dez. 2000.

; PAULINO, Eliane Tomiasi. Terra e território: a questão camponesa no capitalismo. São Paulo: Expressão Popular, 2010.

CALDART, Roseli Salete; PEREIRA, Isabel Brasil; ALENTEJANO, Paulo; FRIGOTTO, Gaudêncio (Orgs.). Apresentação. In: . Dicionário da 
Educação do Campo. Rio de Janeiro: Escola Politécnica de Saúde Joaquim Venâncio; São Paulo: Expressão Popular, 2012. p. 3-21.

CAMPOS, Janaina Francisca de Souza; FERNANDES, Bernardo Mançano. O conceito de paradigma na geografia: limites, possibilidades e contribuições para a interpretação da geografia agrária. Campo-território: revista de geografia agrária, v. 6, n. 11, p. 21-52, fev., 2011.

CHAYANOV, Alexander V. La Organización de la Unidad Económica Campesina. Buenos Aires: Ediciones Nueva Visión, 1974.

FELÍCIO, Munir Jorge. Questão agrária e processos históricos de construção de paradigmas. Revista Geografia em Questão, v. 3, n. 1, p. 61-108, 2010.

FERNANDES, Bernardo Mançano. A ocupação como forma de acesso à terra. In: . A formação do MST no Brasil. Petrópolis: Vozes, 2000. p. 279-301.

- Movimentos socioterritoriais e movimentos socioespaciais: contribuição teórica para uma leitura geográfica dos movimentos sociais. Revista Nera, Presidente Prudente: Unesp, ano 8, n. 6, p. 14 - 34, jan./jun. 2005.

. Questão agrária, pesquisa e MST. São Paulo: Cortez, 2001. (Questões da Nossa época, 92).

. Questão Agrária: conflitualidade e desenvolvimento territorial. In: BUAINAIN, Antônio Márcio (org). Luta pela terra, reforma agrária e gestão de conflitos no Brasil. Campinas: Editora da Unicamp, 2008a. p.173-230.

- Entrando nos territórios do território. Presidente Prudente: Boletim DATALUTA (março), 2008b.

Conflitualidade e desenvolvimento territorial. In: Luta pela Terra, Reforma Agrária e Gestão de Conflitos no Brasil. Campinas: Editora Unicamp, 2008c. 
. Sobre a tipologia de territórios. In: SAQUET, Aurélio Marcos; SPOSITO,

Eliseu Savério (org). Territórios e territorialidades: teorias, processos e conflitos, p. 197-215. São Paulo: Expressão Popular, 2009.

Soberania Alimentar como Território. Presidente Prudente: [s.n], 2010.

; MOLINA, Mônica Castagna. O campo da educação do campo. In: MOLINA, Mônica Castagna; JESUS, Sonia Meire Santos Azevedo de. (Org). Por uma educação do campo: contribuições para a construção de um projeto de educação do campo. Brasília: Articulação Nacional "Por Uma Educação do Campo", 2004, p. 53-91. (Por Uma Educação do Campo, 5).

; WELCH, Clifford Andrew; GONÇALVES, Elienai Constantino. Políticas de agrocombustíveis no Brasil: paradigmas e disputa territorial. [S.l.: s.n.], 2011/prelo.

GÖRGEN, Frei Sergio Antonio. Agrocombustíveis. In: CALDART, Roseli Salete; PEREIRA, Isabel Brasil; ALENTEJANO, Paulo; FRIGOTTO, Gaudêncio (Orgs.). Dicionário da Educação do Campo. Rio de Janeiro: Escola Politécnica de Saúde Joaquim Venâncio; São Paulo: Expressão Popular, 2012. p. 51-57.

. Movimento dos Pequenos Agricultores (MPA). In: CALDART, Roseli Salete; PEREIRA, Isabel Brasil; ALENTEJANO, Paulo; FRIGOTTO, Gaudêncio (Orgs.). Dicionário da Educação do Campo. Rio de Janeiro: Escola Politécnica de Saúde Joaquim Venâncio; São Paulo: Expressão Popular, 2012. p. 492-497.

LEAL, Marcelo. Cooperbio. Uma Cooperativa do Movimento dos Pequenos Agricultores. In: ORTIZ, Lúcia Schild. Construindo a Soberania Energética e Alimentar. Porto Alegre: Núcleo Amigos da Terra/Brasil, 2007.

LEFEBVRE, Henri. The Production of Space. New York: Oxford University Press, 1991. 
MARTINS, José de Souza. Os camponeses e a política no Brasil. Petrópolis: Vozes, 1981.

MCMICHAEL, Philip. A food regime genealogy. London: Journal of Peasant Studies, p.139-169, vol. 36, 2009.

MAPA (Ministério da Agricultura, Pecuária e Abastecimento). Disponível em: $<$ http://www.agricultura.gov.br/>. Acesso em 18 nov. 2011.

MDA (Ministério do Desenvolvimento Agrário). Disponível em: $<$ http://www.mda.gov.br/portal/>. Acesso em 18 nov. 2011.

MÉSZÁROS, István. A educação para além do capital. Tradução de Isa Tavares. São Paulo: Boitempo, 2005.

MÉSZÁROS, István. O desafio e o fardo do tempo histórico: o socialismo no século XXI. Tradução: Ana Cotrim. São Paulo: Boitempo, 2007. (Mundo do Trabalho).

OLIVEIRA, Ariovaldo U. de. A agricultura camponesa no Brasil. 3. ed. São Paulo: Contexto, 1997.

A geografia agrária e as transformações territoriais recentes no campo brasileiro. In: CARLOS, Ana F. A. (Org.). Novos caminhos da geografia. São Paulo: Contexto, 1999. p. 63-137.

. As relações de produção na agricultura sob o capitalismo. In: Modo capitalista de produção e agricultura. São Paulo: Ática, 1986. p. 61-78.

- Geografia agrária: perspectivas no início do século XXI. In: OLIVEIRA, Ariovaldo U. de; MARQUES, Marta Inês Medeiros (Org.). O campo no século XXI: território de vida, de luta e de construção da justiça social. São Paulo: Casa amarela; Paz e Terra, 2004. p. 27-64. 
A recriação dos territórios camponeses por meio da produção de alimentos e energia: 44 a experiência do MPA em Frederico Westphalen-RS, pp. 4-44.

PAULINO, Eliane Tomiasi. A diversidade das lutas na luta pela terra. In: Revista eletrônica da Associação dos Geógrafos Brasileiros: seção Três Lagoas, Três Lagoas, v. 1, ano 3, p.28-47, nov. 2006.

QUIJANO, Escobar. EI laberinto de America Latina: hay otras salidas?. De Econ. Y Ciencias Sociales. 2004.

RAFFESTIN, Claude. Por uma geografia do poder. São Paulo: Ática, 1993.

SHANIN, Teodor. La Classe Incomoda: Sociología política del campesinato en una sociedad em desarrollo (Rússia 1910-1925). Vérsion Española de Fernando Andrada Tápia. Madri: Alianza Editorial, 1983.

STEDILE, João Pedro. O MST e a questão agrária. Estudos Avanzados. Vol. 11, n. 31, p. 69-97. 1997.

STEDILE, João Pedro. Soberania alimentar, o que é isso? Revista Caros Amigos, São Paulo: Casa Amarela, ano 10, n. 120, p. 42, mar. 2007.

TERRITÓRIOS DA CIDADANIA. Disponível em: $<$ http://www.territoriosdacidadania.gov.br/>. Acesso em 18 nov. 2011.

THOMAZ JR., Antônio. Trabalho, Reforma Agrária e Soberania Alimentar (Em Questão a Classe Trabalhadora e a Luta de Classes no Brasil). Revista Geocrítica (Versão resumida). Barcelona, 2007. Disponível em: $<$ http://www.ub.es/geocrit/9porto/thomaz.htm>.

WITTMAN, Hannah. Food Sovereignty: a new rights framework for food and nature?. Nova Iorque: Environment and Society; Berghahn Journals, 2011. p. 87-105.

WOORTMANN, Klaas. Com parente não se negoceia: o campesinato como ordem moral. Anuário antropológico, Rio de Janeiro: Tempo Brasileiro, n. 87, p. 1173, 1990. 